\title{
Characterization of the cDNA of a Broadly Reactive Neutralizing Human Anti-gp120 Monoclonal Antibody
}

\author{
Wayne A. Marasco, Jessamyn Bagley, Christy Zani, Marshall Posner, * Lisa Cavacini, * \\ William A. Haseltine, and Joseph Sodroski \\ Division of Human Retrovirology, Dana Farber Cancer Institute, Harvard Medical School, Boston, Massachusetts 02115; and \\ *Department of Medicine, New England Deaconess Hospital Harvard Medical School, Boston, Massachusetts 02115
}

\begin{abstract}
The F105 mAb, identified in an HIV-1-infected individual, binds to a discontinuous epitope on the HIV-1 gp1 20 envelope glycoprotein, blocks the binding of gp120 to the CD4 viral receptor, and neutralizes a broad range of HIV-1 isolates. This study reports the primary nucleotide and deduced amino acid sequences of the rearranged heavy and light chains of the $\mathrm{mAb}$ F105. This IgG $\mathrm{I} \mathrm{mAb}$ uses a $V_{H}$ gene member of the $V_{H^{4}}$ gene family (V71-4) and is productively rearranged with a $D-D$ fusion product of the dlr 4 and da4 germline $D_{H}$ genes and the $J_{H 5}$ gene. This rearranged heavy chain gene expresses the $V_{H^{4-H V} 2 a}$ idiotope, which is seen in human monoclonal IgM cold agglutinins. The $F 105 V_{k}$ appears to be derived from the Humvk325 germline gene and is rearranged with a $J_{k 2}$ gene. For both chains, the mutational pattern in the rearranged $V_{H}$ and $V_{L}$ genes is indicative of an antigen-driven process. These studies show that production of a broadly neutralizing antiHIV-1 antibody that recognizes determinants within the CD4 recognition site of the envelope glycoprotein is achieved by rearrangement of the V71-4 and Humvk325 germline variable region genes along with selected individual point mutations in the rearranged genes. (J. Clin. Invest. 1992. 90:1467-1478.) Key words: acquired immunodeficiency syndrome • immunoglobulins • gene rearrangement $\bullet$ autoantibody $\bullet$ restricted idiotype
\end{abstract}

\section{Introduction}

HIV-1 productively infects human CD4+ cells, including CD4+ T cells and cells of the monocyte/macrophage lineage (1-5). The first step in infection by HIV-1 is the specific binding of gp 120, the envelope glycoprotein of HIV-1, to its cellular receptor, the CD4 molecule $(6,7)$. Infection with HIV-1 leads, in most cases, to a progressive decline in the number and functions of CD4+ $\mathrm{T}$ cells with the eventual appearance of clinical manifestations of cellular immunodeficiency, such as opportunistic infections and malignancies, i.e., AIDS (8).

Serum antibodies reacting with the HIV-1 gp120 can neutralize viral infection by binding to several sites on the molecule $(9,10)$. The earliest neutralizing human antibody re-

Address correspondence to Wayne A. Marasco, M. D., Ph. D., Division of Human Retrovirology, Dana-Farber Cancer Institute, 44 Binney Street, Boston, MA 02115.

Received for publication 26 November 1991 and in revised form 5 March 1992.

J. Clin. Invest.

(C) The American Society for Clinical Investigation, Inc. $0021-9738 / 92 / 10 / 1467 / 12 \$ 2.00$

Volume 90, October 1992, 1467-1478 sponse is directed to epitopes in the third hypervariable region of gp120, the principle neutralizing domain, which is contained within a loop formed by disulfide bonding (11-13). These antibodies are frequently strain specific (14). Envelope glycoprotein variation both within the linear epitope and outside the epitope can allow escape of viruses from neutralization by these antibodies $(15,16)$. Later in the course of HIV-1 infection, more broadly neutralizing antibodies appear (17). A large fraction of these broadly neutralizing antibodies, which are present in low concentrations in patients' sera, are directed to conformationally sensitive epitopes on gp120 (18, 19). A subset of the broadly reactive antibodies, found in the serum of patients, interferes with the binding of gp120 and CD4 (10, 20-22). These antibodies appear to be reactive with a discontinuous epitope on gp 120 that encompasses the CD4 binding region $(23,24)$. This region of gp1 20 is well conserved although not invariant.

Several human mAbs derived from HIV-infected individuals, which block CD4 binding, recognize conformation-dependent epitopes on gp120, and neutralize a broad range of HIV-1 isolates, have recently been described (25-27). One of these human mAbs is $\mathrm{F} 105(25)$. This $\operatorname{IgG}_{1} \mathrm{k}$ antibody reacts with a conformationally defined epitope on HIV-1/gp120, which appears to be within or topographically near the CD4-binding site $(24,25)$. This $m A b$ recognizes an epitope on the surfaces of HIV-1-infected malignant $T$ cell and monocyte cell lines and on intact virions. In addition, F105 neutralizes a number of diverse HIV-1 isolates, including IIIB, MN, RF, and $\mathrm{SF}_{2}$ strains (25). This antibody is potentially useful in immunoprophylaxis after exposure, in preventing the vertical transmission of HIV, and in monitoring the humoral immune response in HIV-1-infected individuals and vaccinated volunteers.

One of the aims of elucidating nucleotide sequences of antibodies specific for a single antigen is to determine the extent of diversity or restriction in the use of germ line genes (28). Recently, the primary nucleotide and deduced amino acid sequences of several human anti-gp120 V3 loop and anti-gp41 heavy chains have been reported $(29,30)$. To understand the molecular nature of the broadly neutralizing human antibodies that are directed at or near the CD4-binding domain of gp 120 , the rearranged heavy and light chains of the F105 mAb were cloned. These studies provide the first molecular characterization of the broadly neutralizing anti-gp120 antibodies and form the basis for future molecular studies aimed at investigating the humoral immune response to the CD4-binding domain of $\mathrm{gp} 120$.

\section{Methods}

cDNA synthesis and polymerase chain reaction amplification of F105 immunoglobulin genes. The F105 hybridoma was derived by fusion of 
EBV transformants with the HMMA2.11TG/0 cell line, a nonsecreting human-mouse myeloma analogue (25). Both cell lines were used for CDNA synthesis and polymerase chain reaction (PCR) ${ }^{1}$ amplification experiments. First strand CDNA was synthesized in a $25-\mu 1$ reaction from $5 \mu \mathrm{g}$ of total RNA by using oligo(dT) priming and the Moloney murine-leukemia virus reverse transcriptase according to published protocols (31). 5-10\% of the first strand cDNA was used to perform the PCR reactions. The temperatures used for the PCR are melt $94^{\circ} \mathrm{C}, 1 \mathrm{~min}$; primer anneal $52^{\circ} \mathrm{C}, 2 \mathrm{~min}$; primer extension $72^{\circ}, 2$ min. 1-min ramp times were used except a 2 -min ramp time was used between annealing and extension. Ethidium bromide-stained $2 \%$ agarose gels were use to separate the PCR fragments. The appropriate band was excised, gene cleaned (Bio 101, Inc., La Jolla, CA), Klenow repaired, restriction enzyme digested and cloned into pSL1 180 (Pharmacia LKB Biotech. Inc., Piscataway, NJ) using SURE bacteria (Stratagene Inc., La Jolla, CA) as hosts. At least three separate transformants were sequenced using both forward and reverse sequencing primers. DNA sequence analysis was performed by the method of Sanger et al. (32). The sequencing primers were designed to be complementary to the polylinker sequences of pSL1 180.

The heavy chain primer pair consists of a $V_{H}$ primer and a $J_{H}$ or $C_{H 1}$ primer, each containing convenient restriction sites for cloning. The Kabat database on immunoglobulins was used to analyzed the amino acid and codon distribution found in the six distinct human $V_{H}$ families (33). Based on this analysis, the 35-bp universal $5^{\prime} \mathrm{V}_{\mathrm{H}}$ primer was designed TTTGCGGCCGCTCAGGTGCA(G/A)CTGCTCGAGTC(T/C)GG, which is degenerate for two different nucleotides at two positions and will anneal to the 5' end of FR1 sequences. A 5' NotI site (left-underlined) has been introduced for cloning the amplified DNA and is located $5^{\prime}$ to the first codon of the $V_{H}$ gene. An internal XhoI site has been introduced as well (right-underlined). Similarly, a 35-bp $\mathbf{J}_{\mathbf{H}}$ region oligonucleotide has been designed for reverse priming at the $3^{\prime}$ end of the heavy chain variable gene, TTAGCGCGCTGAGGTGACCGTGACC $(A / G)(G / T) G G T$. Based on the nucleotide sequence of the six human $\mathrm{J}_{\mathrm{H}}$ region minigenes, this primer contains two degenerate positions with two nucleotides at each position. A BssHII site (left-underlined ) 3 ' to and immediately adjacent to the codon determining the last amino acid of the $\mathrm{J}$ region allows convenient cloning at the $3^{\prime}$ end of the $V_{H}$ gene. An internal BstEII site (right-underlined) has been introduced as well. To obtain unbiased sequence data in the $J_{H}$ region, a reverse $\operatorname{IgG}_{1} \mathrm{C}_{\mathrm{H} 1}$ primer was designed, which terminates just $3^{\prime}$ of the first cysteine codon in the hinge exon, TTAGCGCGCACAAGATTTGGGCTC (33). A BssHII site was similarly introduced for cloning. The resulting gene product ( $\mathrm{H}$ fragment) was intended to correspond to a $\mathrm{Fd}$ of $\mathrm{IgG}_{1}$ isotype and conserves the $\mathrm{H}-\mathrm{L}$ disulfide bond (34). A primer corresponding to amino acids 183 to 189 of $\mathrm{IgG}_{1} \mathrm{CH} 1$ region was used for DNA sequencing, TGCTGAGGGAGTAGAGT.

A similar strategy has been used to design PCR primers for the human kappa chain variable genes. There are four families of human $\mathrm{V}_{\text {kappa }}$ genes. The $5^{\prime} \mathrm{V}_{\text {kappa }}$ primer TTTGCGGCCGCTGAGCTC(G/ C)(T/A)G(A/C)TGACCCAGTCTCCA, which will anneal to the $5^{\prime}$ end of the FR 1 sequences, is degenerate at three positions (two nucleotides each) and contains a Not I (left-underlined) site at a position similar to that of the $V_{H}$ region. An internal Sac $I$ site is also present (right-underlined). The reverse 39-bp $\mathrm{J}_{\text {kappa }}$ primer CGAGGATCCTTATTAACGCGTGATCTCCA(C/G)(C/T)TTGGTCCC, designed from the sequence of five human $\mathrm{J}_{\text {kappe }}$ minigenes, is degenerate at three positions (two nucleotides at each position) and contains an internal Mlu I site (right-underlined) immediately flanking the $\mathbf{J}_{\text {kappe }}$ coding region and is then followed by two stop codons and a BamHI cloning site (left-underlined). To obtain unbiased sequence data in the $\mathrm{J}_{\mathrm{kappa}}$ region, two reverse kappa constant region primers were designed. The first primer CGAGGATCCTTATTAACGCGTTGGTGCAGCC-

1. Abbreviations used in this paper: $\mathrm{CDR}$, complementarity determining region; FR, framework; PCR, polymerase chain reaction; TBS-T, Tris-buffered saline containing $0.2 \%$ Tween 20 .
ACAGT will anneal to the most $5^{\prime}$ end of the kappa constant region and has a similar flanking sequence arrangement as the $\mathrm{J}_{\text {kappe }}$ primer. A second primer TGGGGATCCTTATTAACACTCTCCCCTGTTGAA was designed to anneal to the most $3^{\prime}$ kappa constant region nucleotides and this region is followed by two stop codons and a BamHI cloning site.

After the primary nucleotide sequence was determined for both the F105 heavy and kappa chain genes and the germ line genes were identified, PCR primers were designed based on the leader sequences of the $\mathrm{V}_{\mathbf{H}}$ 71-4 (35) and Humvk325 (36) germ line genes. The $\mathrm{V}_{\mathbf{H}}$ 71-4 leader primer TTTACCATGGAACATCTGTGGTTC and the Humvk325 leader primer GGAACCATGGAAACCCCAGCGCAG both contain a $5^{\prime} \mathrm{Ncol}$ site (underlined). These leader primers were used in conjunction with the respective $C$ region primers for PCR amplification experiments.

ELISA. F105, or IgM ODO (a gift from Dr. Gregg Silverman, University of California, San Diego, CA) were resuspended in coating buffer ( $100 \mathrm{mM}$ sodium carbonate, $\mathrm{pH} 8.5$ ) at $150 \mathrm{ng} / \mathrm{ml}$ and incubated overnight ( $100 \mu \mathrm{l} /$ well) at $4^{\circ}$ on ELISA plates (Immulon No. 1; Dynatech Labs, Inc., Chantilly, VA). After washing with Tris-buffered saline containing $0.2 \%$ Tween 20 (TBS-T) and blocking with TBS-T containing $1 \% \mathrm{BSA}$, the plates were incubated at varying concentrations with various rabbit anti-peptide antisera that recognize $V_{H}$ III or IV framework or $V_{H}$ IV CDR2 determinants (37). A rabbit antisera raised against an unrelated peptide served at a negative control (rabbit anti-formyl Met-Leu-Phe/BSA). In some cases CDR2 peptides were preincubated at $1 \mu \mathrm{g} / \mathrm{ml}$ with anti-CDR2 peptide antisera for $1 \mathrm{~h}$ at room temperature before addition to the plate. After overnight incubation the plates were washed extensively and bound rabbit antibody was detected with affinity column-purified, alkaline phosphatase-coupled goat anti-rabbit IgG that had been absorbed with human serum (Sigma Chemical Co., St. Louis, MO) and p-nitrophenylphosphate as alkaline phosphatase substrate (BioRad Laboratories, Richmond, CA) per manufacturer's instructions. Absorption at $405 \mathrm{~nm}$ was recorded using an ELISA reader (Titertek Multiskan Plus; Labsystems, Inc., Finland).

Cold agglutinin and rheumatoid factor assays. For cold agglutinin activity, $200 \mu \mathrm{l}$ of $\mathrm{F} 105(1 \mathrm{mg} / \mathrm{ml})$ was diluted 10 -fold in $6 \%$ BSA and then tested against reagent human red cells with the following phenotypes: $\mathrm{A}_{1}, \mathrm{I}$, low $\mathrm{H} ; \mathrm{B}, \mathrm{I}$, mid-range $\mathrm{H} ; \mathrm{O}$, I, strong $\mathrm{H}$; and $\mathrm{O}$, i, strong $\mathrm{H}$. Antibody was tested against each cell at $22^{\circ} \mathrm{C}, 18^{\circ} \mathrm{C}$, and $4^{\circ} \mathrm{C}$. Reactions were tested by both direct hemagglutination and also using mouse monoclonal anti-human IgG (Coombs sera).

For rheumatoid factor activity, various dilutions of F105 were mixed with human IgG-coated latex particles and assayed for agglutination.

\section{Results}

F105 heavy chain $V_{H}$ gene is derived from germ line $V_{H} I V$ 71-4. The F105 hybridoma cell line was used as the source of mRNA. First strand cDNA was prepared by the method of Gubler and Hoffman (31) and 5-10\% of this reaction mixture was used in the PCR experiments. The degenerate $V_{H}$ and $J_{H}$ primers were initially used to amplify by PCR an $\sim 370$-nucleotide fragment. This is the expected molecular weight of the rearranged heavy chain gene. This amplified DNA was inserted into the pSL1180 plasmid. Subsequent to the identification of the germ line $V_{H}$ gene, the cDNA was reamplified using primers that recognize the leader and $\mathrm{IgG}_{1}$ constant regions to obtain unbiased DNA sequence information of the FR 1 and $J_{H}$ regions.

DNA sequence analysis was performed by the method of Sanger et al. (32). The results revealed that the rearranged F105 $\mathrm{V}_{\mathrm{H}}$ gene is derived from a member of the $\mathrm{V}_{\mathrm{H}} \mathrm{IV}$ gene family as evidenced by $>88 \%$ similarity with all of the 
members of the germ line $\mathrm{V}_{\mathrm{H}}$ genes that have been described by Lee (35) (data not shown). This $\mathrm{V}_{\mathbf{H}}$ gene family has $\sim 10$ members. F105 $\mathrm{V}_{\mathrm{H}}$ shares greatest sequence similarity with germ line gene $\mathrm{V}_{\mathrm{H}} 71-4(94.8 \%, 285 / 297$ nucleotides) (Table I). There are a total of 12 nucleotide changes in F105 com- pared with $\mathrm{V}_{\mathrm{H}}$ 71-4 and these changes are summarized in Table II. Nine of the changes are in the framework residues and are distributed in all three framework regions (FRs). These changes include four transitions and five transversions. The remaining three changes are all transitions and occur in the

Table I. Nucleotide Sequence Comparison of F105 $V_{H}$ and Several Similar Germ Line $V_{H} I V$ Genes

\begin{tabular}{|c|c|c|c|c|c|c|c|c|c|c|c|c|c|c|c|c|}
\hline & -19 & & & & & & & & & -10 & & & & & & \\
\hline $\mathrm{V}_{\mathbf{H}} 71-4:$ & ATG & AAA & CAT & CTG & TGG & TTC & TTC & CTT & CTC & CTG & GTG & GCA & GCT & CCC & AGA & $\mathrm{T} / \mathrm{GG}$ \\
\hline $\mathrm{F} 105 \mathrm{~V}_{\mathrm{H}}$ & -- & $\cdots$ & -- & --- & --- & -- & $\cdots$ & $\ldots$ & $\cdots$ & $\cdots$ & $\cdots$ & $\cdots$ & $\cdots$ & $\cdots$ & $\cdots$ & . \\
\hline VH411: & $\cdots$ & $\cdots$ & $\cdots$ & $\cdots$ & $\cdots$ & $\cdots$ & $\cdots$ & $\cdots$ & $\cdots$ & $\ldots$ & $\cdots$ & $\ldots$ & $\ldots$ & $\cdots$ & $\ldots$ & . \\
\hline VH415: & $\ldots$ & $\ldots$ & $\ldots$ & $\ldots$ & $\ldots$ & $\ldots$ & $\ldots$ & $\ldots$ & $\ldots$ & $\ldots$ & $\ldots$ & $\ldots$ & $\ldots$ & $\ldots$ & $\ldots$ & . . \\
\hline VH416: & $\cdots$ & $\cdots$ & $\cdots$ & $\cdots$ & $\cdots$ & $\ldots$ & $\ldots$ & $\ldots$ & $\cdots$ & $\ldots$ & $\ldots$ & $\ldots$ & $\ldots$ & $\ldots$ & $\ldots$ & . \\
\hline & & & & 1 & & & & & & & & & 10 & & & \\
\hline$V_{H} 71-4:$ & GTC & CTG & TCC & CAG & GTG & CAG & CTG & CAG & GAG & TCG & GGC & CCA & GGA & CTG & GTG & AAG \\
\hline $\mathrm{F} 105 \mathrm{~V}_{\mathrm{H}}$ : & $\cdots$ & $\cdots$ & $\cdots$ & $\cdots$ & $\cdots$ & $\cdots$ & $\cdots$ & $\cdots$ & $\cdots$ & $\cdots$ & $\cdots$ & $\ldots$ & $\cdots$ & $\cdots$ & $\ldots$ & $\ldots$ \\
\hline VH411: & $\ldots$ & $\ldots$ & $\ldots$ & $\ldots$ & $\ldots$ & $\ldots$ & $\ldots$ & $\ldots$ & $\ldots$ & $\ldots$ & $\ldots$ & $\ldots$ & $\ldots$ & $\ldots$ & $\ldots$ & $\ldots$ \\
\hline VH415: & $\ldots$ & $\ldots$ & $\ldots$ & $\ldots$ & $\ldots$ & $\ldots$ & $\ldots$ & $\ldots$ & $\ldots$ & $\ldots$ & $\ldots$ & $\ldots$ & $\ldots$ & $\ldots$ & $\ldots$ & $\ldots$ \\
\hline VH416: & $\cdots$ & $\cdots$ & $\cdots$ & $\cdots$ & $\cdots$ & $\cdots$ & $\cdots$ & $\cdots$ & $\cdots$ & $\ldots$ & $\cdots$ & $\ldots$ & $\ldots$ & $\cdots$ & $\cdots$ & $\ldots$ \\
\hline & & & & & & & 20 & & & & & & & & & \\
\hline $\mathrm{V}_{\mathrm{H}} 71-4:$ & $\mathrm{CCT}$ & TCG & GAG & $\mathrm{ACC}$ & CTG & $\mathrm{TCC}$ & CTC & $\mathrm{ACC}$ & TGC & $\mathrm{ACT}$ & GTC & TCT & GGT & GGC & $\mathrm{TCC}$ & GTC \\
\hline $\mathrm{F} 105 \mathrm{~V}_{\mathrm{H}}$ & $\ldots$ & $\ldots$ & $\ldots$ & $\ldots$ & $\ldots$ & $\ldots$ & $\cdots$ & $\ldots$ & $\cdots$ & $\cdots$ & $\cdots$ & $\ldots$ & $\ldots \mathrm{A}$ & $\ldots$ & $\ldots$ & A.. \\
\hline VH411: & $\ldots$ & $\ldots$ & $\ldots$ & $\ldots$ & $\ldots$ & $\ldots$ & $\ldots$ & $\ldots$ & $\ldots$ & $\ldots$ & $\ldots$ & $\ldots$ & $\ldots$ & $\ldots$ & $\ldots$ & A. . \\
\hline VH415: & $\ldots$ & $\ldots$ & $\ldots$ & $\cdots$ & $\ldots$ & $\ldots$ & $\cdots$ & $\ldots$ & $\ldots$ & & $\ldots$ & $\ldots$ & $\cdots$ & $\ldots$ & $\ldots$ & \\
\hline VH416: & $\cdots$ & $\ldots$ & $\ldots C$ & $\ldots$ & $\ldots$ & $\ldots$ & $\ldots$ & $\ldots$ & $\cdots$ & $\ldots$ & $\ldots$ & $\ldots$ & $\ldots$ & $\ldots$ & $\ldots$ & A. . \\
\hline & 30 & & & & CDR & & & & & & & & & 40 & & \\
\hline $\mathrm{V}_{\mathbf{H}} 71-4:$ & AGT & $* * *$ & $* * *$ & AGT & $* * *$ & TAC & TAC & TGG & AGC & TGG & ATC & CGG & CAG & $\mathrm{CCC}$ & CCA & GGG \\
\hline $\mathrm{F} 105 \mathrm{~V}_{\mathrm{H}}$ & $\cdots$ & $\cdots$ & $\ldots$ & $\cdots$ & $\ldots$ & C. & $\cdots$ & $\cdots$ & $\cdots$ & $\cdots$ & $\ldots$ & $\ldots$ & $\ldots$ & T. & $\ldots$ & $\ldots$ \\
\hline VH411: & $\cdots$ & $\cdots$ & $\cdots$ & $\cdots$ & $\cdots$ & $\cdots$ & $\cdots$ & $\cdots$ & $\cdots$ & $\cdots$ & $\cdots$ & $\cdots$ & $\cdots$ & $\cdots$ & $\cdots$ & $\cdots$ \\
\hline VH415: & $\cdots$ & $\cdots$ & $\cdots$ & $\cdots$ & $\cdots$ & $\cdots$ & $\ldots$ & $\cdots$ & $\cdots$ & $\ldots$ & $\ldots$ & $\cdots$ & $\cdots$ & $\cdots$ & $\cdots$ & $\ldots$ \\
\hline VH416: & $\cdots$ & $\cdots$ & $\cdots$ & $\cdots$ & $\ldots$ & $\ldots$ & $\cdots$ & $\cdots$ & $\cdots$ & $\cdots$ & $\cdots$ & $\cdots$ & $\cdots$ & $\cdots$ & $\cdots$ & $\cdots$ \\
\hline & & & & & & & & 50 & & & & DR2 & & & & \\
\hline $\mathrm{V}_{\mathbf{H}} 71-4:$ & AAG & GGA & CTG & GAG & TGG & ATT & GGG & TAT & ATC & TAT & $\mathrm{TAC}$ & $\mathrm{AGT}$ & GGG & AGC & $\mathrm{ACC}$ & AAC \\
\hline $\mathrm{F} 105 \mathrm{~V}_{\mathrm{H}}$ : & $\cdots$ & $\cdots$ & $\cdots$ & C. . & $\ldots$ & $\cdots$ & $\ldots \mathrm{A}$ & $\ldots$ & $\cdots$ & $\ldots \mathrm{C}$ & $\cdots$ & $\cdots$ & $\cdots$ & $\cdots$ & $\cdots$ & $\cdots$ \\
\hline VH411: & $\ldots$ & $\cdots$ & $\cdots$ & $\cdots$ & $\cdots$ & $\cdots$ & $\ldots$ & $\cdots$ & $\cdots$ & $\ldots$ & $\cdots$ & $\cdots$ & $\cdots$ & $\cdots$ & $\ldots$ & $\ldots$ \\
\hline VH415: & $\cdots$ & $\cdots$ & G. . & $\ldots$ & $\ldots$ & $\ldots$ & $\ldots$ & $\cdots$ & $\cdots$ & $\cdots$ & $\ldots$ & $\cdots$ & & $\ldots$ & $\ldots$ & $\ldots$ \\
\hline VH416: & $\ldots$ & $\cdots$ & $\ldots$ & $\cdots$ & $\ldots$ & $\ldots$ & $\ldots$ & & $\ldots$ & & & $\ldots$ & & & $\ldots$ & $\ldots$ \\
\hline & & 60 & & & & & & & & & & 70 & & & & \\
\hline $\mathrm{V}_{\mathbf{H}} 71-4:$ & TAC & $\mathrm{AAC}$ & $\mathrm{CCC}$ & TCC & CTC & AAG & AGT & CGA & GTC & ACC & ATA & TCA & GTA & GAC & ACG & TCC \\
\hline $\mathrm{F} 105 \mathrm{~V}_{\mathrm{H}}$ : & $\cdots$ & G. & $\cdots$ & $\cdots$ & $\cdots$ & $\cdots$ & $\cdots$ & $\cdots$ & $\cdots$ & $\cdots$ & $\cdots$ & $\cdots$ & $\cdots$ & . G & $\cdots$ & $\cdots$ \\
\hline VH411: & $\cdots$ & $\cdots$ & $\cdots$ & $\cdots$ & $\cdots$ & $\cdots$ & $\cdots$ & $\cdots$ & $\cdots$ & $\cdots$ & $\cdots$ & $\cdots$ & $\cdots$ & $\cdots$ & $\cdots$ & $\cdots$ \\
\hline VH415: & $\cdots$ & $\cdots$ & $\cdots$ & $\cdots$ & $\cdots$ & $\cdots$ & $\cdots$ & $\cdots$ & $\cdots$ & $\cdots$ & $\cdots$ & $\cdots$ & $\cdots$ & $\cdots$ & $\cdots$ & $\cdots$ \\
\hline VH416: & $\cdots$ & $\cdots$ & $\cdots$ & $\cdots$ & $\cdots$ & $\cdots$ & $\cdots$ & $\cdots$ & $\cdots$ & $\cdots$ & $\ldots$ & $\cdots$ & $\cdots$ & $\cdots$ & $\cdots$ & $\ldots$ \\
\hline & & & & & & 80 & & & & & & & & & & \\
\hline $\mathrm{V}_{\mathrm{H}} 71-4:$ & AAG & $\mathrm{AAC}$ & CAG & TTC & TCC & CTG & AAG & CTG & AGC & TCT & GTG & $\mathrm{ACC}$ & GCT & GCG & GAC & $\mathrm{ACG}$ \\
\hline $\mathrm{F} 105 \mathrm{~V}_{\mathrm{H}}$ : & $\cdots$ & $\cdots$ & $\cdots$ & $\ldots$ & $\cdots$ & $\cdots$ & $\cdots$ & $\cdots$ & C. & $\cdots$ & A. . & $\cdots$ & $\cdots$ & $\cdots$ & $\cdots$ & \\
\hline VH411: & $\cdots$ & $\cdots$ & $\cdots$ & $\cdots$ & $\cdots$ & $\ldots$ & $\cdots$ & & $\cdots$ & $\cdots$ & $\cdots$ & $\cdots$ & & $\cdots$ & $\ldots$ & \\
\hline VH415: & $\cdots$ & $\cdots$ & $\cdots$ & $\cdots$ & $\cdots$ & $\cdots$ & $\cdots$ & $\cdots$ & $\ldots$ & $\cdots$ & $\cdots$ & $\cdots$ & $\cdots$ & & & $\ldots$ \\
\hline VH416: & $\cdots$ & $\cdots$ & $\cdots$ & $\cdots$ & $\cdots$ & $\cdots$ & $\cdots$ & $\cdots$ & $\cdots$ & $\ldots$ & $\ldots$ & $\cdots$ & $\cdots$ & $\ldots$ & $\cdots$ & $\ldots$ \\
\hline & & & 90 & & & & & & & & & & & & & \\
\hline $\mathrm{V}_{\mathbf{H}} 71-4:$ & GCC & GTG & TAT & TAC & TGT & GCG & AGA & & & & & & & & & \\
\hline $\mathrm{F} 105 \mathrm{~V}_{\mathrm{H}}:$ & $\cdots$ & $\cdots$ & $\cdots$ & $\cdots$ & $\cdots$ & $\ldots$ & C.. & & & & & & & & & \\
\hline VH411: & $\cdots$ & $\cdots$ & $\cdots$ & $\cdots$ & $\cdots$ & $\cdots$ & $\cdots$ & & & & & & & & & \\
\hline VH415: & $\cdots$ & $\cdots$ & $\cdots$ & $\cdots$ & $\cdots$ & $\cdots$ & $\cdots$ & & & & & & & & & \\
\hline VH416: & $\cdots$ & $\cdots$ & $\cdots$ & $\cdots$ & $\ldots$ & $\ldots$ & & & & & & & & & & \\
\hline
\end{tabular}

Dashes after F105 represent primer annealing sequences. 
Table II. Summary of Differences between F105 and Germline Genes $V_{H} 71-4$ and Hum vk325

\begin{tabular}{|c|c|c|c|c|c|c|c|}
\hline \multirow[b]{2}{*}{ Position } & \multirow[b]{2}{*}{ Location } & \multicolumn{2}{|c|}{ Nucleotide } & \multirow[b]{2}{*}{ Change } & \multicolumn{2}{|c|}{ Amino acid } & \multirow[b]{2}{*}{ Change } \\
\hline & & $71-4$ & F105 & & $71-4$ & F105 & \\
\hline
\end{tabular}

A. Summary of differences between F105 $V_{H}$ and germ line $V_{H}$ 71-4

$\begin{array}{llllllll}26 & \text { FR1 } & \text { T } & \text { A } & \text { TV } & \text { Gly } & \text { Gly } & \text { Silent } \\ 29 & \text { FR1 } & \text { G } & \text { A } & \text { TS } & \text { Val } & \text { lle } & \text { Conservative } \\ 32 & \text { CDR1 } & \text { T } & \text { C } & \text { TS } & \text { Tyr } & \text { His } & \text { Nonconservative } \\ 40 & \text { FR2 } & \text { C } & \text { T } & \text { TS } & \text { Pro } & \text { Ser } & \text { Nonconservative } \\ 46 & \text { FR2 } & \text { G } & \text { C } & \text { TV } & \text { Glu } & \text { Gln } & \text { Nonconservative } \\ 49 & \text { FR2 } & \text { G } & \text { A } & \text { TS } & \text { Gly } & \text { Gly } & \text { Silent } \\ 52 & \text { CDR2 } & \text { T } & \text { C } & \text { TS } & \text { Tyr } & \text { Tyr } & \text { Silent } \\ 60 & \text { CDR2 } & \text { A } & \text { G } & \text { TS } & \text { Asn } & \text { Ser } & \text { Semiconservative } \\ 72 & \text { FR3 } & \text { C } & \text { G } & \text { TV } & \text { Asp } & \text { Glu } & \text { Conservative } \\ 82 \mathrm{~A} & \text { FR3 } & \text { G } & \text { C } & \text { TV } & \text { Ser } & \text { Thr } & \text { Conservative } \\ 82 C & \text { FR3 } & \text { G } & \text { A } & \text { TS } & \text { Val } & \text { Met } & \text { Conservative } \\ 94 & \text { FR3 } & \text { A } & \text { C } & \text { TV } & \text { Arg } & \text { Arg } & \text { Silent }\end{array}$

B. Summary of differences between $\mathrm{F} 105 \mathrm{~V}_{\mathbf{k}}$ and germ line Humvk325

\begin{tabular}{|c|c|c|c|c|c|c|c|}
\hline \multirow[b]{2}{*}{ Position } & \multirow[b]{2}{*}{ Location } & \multicolumn{2}{|c|}{ Nucleotide } & \multirow[b]{2}{*}{ Change } & \multicolumn{2}{|c|}{ Amino acid } & \multirow[b]{2}{*}{ Change } \\
\hline & & $v k 325$ & F105 & & $v k 325$ & F105 & \\
\hline 15 & FR1 & $\mathrm{C}$ & G & TV & Pro & Ala & Nonconservative \\
\hline 31 & CDR1 & $\mathrm{C}$ & G & TV & Ser & Arg & Nonconservative \\
\hline 78 & FR3 & $\mathrm{C}$ & G & TV & Leu & Val & Conservative \\
\hline 90 & CDR3 & G & A & TS & Glu & Glu & Silent \\
\hline 92 & CDR3 & G & A & TS & Gly & Asp & Nonconservative \\
\hline 93 & CDR3 & A & $\mathrm{C}$ & TV & Ser & Ser & Silent \\
\hline 94 & CDR3 & G & A & TS & Ser & Asn & Nonconservative \\
\hline $95 \mathrm{~A}$ & CDR3 & $\mathrm{C}$ & G & TV & Pro & Val & Nonconservative \\
\hline $95 \mathrm{~B}$ & CDR3 & $\mathrm{C}$ & $\mathrm{T}$ & TS & Pro & Val & Nonconservative \\
\hline
\end{tabular}

TS, transition; TV, transversion.

CDR1 and CDR2 regions. Table I also compares the nucleotide sequence of $F 105 V_{H}$ with three additional nonrearranged $V_{H}$ IV germ line genes $\left(V_{H} 4.11,4.15\right.$, and 4.16) that are most closely related to $V_{H} 71-4$ (38). All three of these germ line genes and F105 share the guanosine to adenosine; valine to isoleucine change in position 29 supporting the possibility that this change may represent an allelic polymorphism. F105 however has many more nucleotide changes (12) compared with these genes (one, 4.11; or two, 4.15 and 4.16), suggesting that additional somatic mutations might have arisen in F105 after recombination.

At the amino acid level, four of the F105 $\mathrm{V}_{\mathrm{H}}$ nucleotide changes result in silent mutations that are distributed equally in each of the three FR regions (positions 26,FR1; 49,FR2; 94,FR3) and there is one silent mutation in CDR2 (position 52). The remaining eight nucleotide changes result in amino acid changes that occur in the three FRs more frequently than in the CDRs ( Table II). Two nonconservative changes occur in the FR2 region and three conservative changes occur in the FR3 region. One additional FR1 region framework residue at position 29 , which results in a conservative change valine to isoleucine, is located immediately adjacent to the complementarity determining region (CDR) defined by Kabat et al. (33). This region may also contribute to the topography of the anti- body-combining site (39). The presence of isoleucine at position 29 in four of seven germ line $V_{H}$ IV genes suggests that isoleucine may represent an allelic difference and not a somatic mutation $(35,38)$. In the CDR regions, two changes occur with a non-conservative replacement of tyrosine to histidine in CDR1, position 32 and a semiconservative change of asparagine to serine in CDR2, position 60. The ratio of substitution to silent mutations is $2: 1$. The substitution mutations occur in a FR/CDR ratio of 3:1.

Comparative analysis of F105 $V_{H}$ and other $V_{H}$ 71-4-derived rearranged $V_{H}$ genes. Table III, A compares the nucleotide sequence of F105 $V_{H}$ to two mAbs that, by nucleotide sequence analysis, appear to use a rearranged $V_{H}$ 71-4 gene. One IgM lambda mAb (Ab26) was derived from $\mathrm{CD}^{+} \mathrm{B}$ cells of a healthy donor and represents a naturally occurring polyreactive antibody that binds to many antigens (40). Ab26 has greatest sequence similarity with $\mathrm{V}_{\mathbf{H}} 71-4(92.3 \%)$ compared with the next closest germ line gene $V_{H} 71-2(89.5 \%)$. Also shown in Table III is antibody $268-\mathrm{D}$, an IgG $_{1} \mathrm{mAb}$ that is specific for the principle neutralizing domain of gp 120 of HIV1 strain $M N$ and is $88.5 \%$ identical to $V_{H} 71-4$ (29). As can be seen in Table III, all three of these $V_{H}$ 71-4-related heavy chains have undergone extensive somatic mutation with F105 showing the least number of nucleotide changes. For mAbs Ab26 
A. Nucleotide Sequence Comparison of F105 $V_{H}$ to Somatic Rearranged $V_{H}$ 71-4 Genes

\begin{tabular}{|c|c|c|c|c|c|c|c|c|c|c|c|c|c|c|c|c|}
\hline & -19 & & & & & & & & & -10 & & & & & & \\
\hline $\mathrm{V}_{\mathbf{H}} 71-4:$ & ATG & AAA & CAT & CTG & TGG & TTC & TTC & СТT & CTC & CTG & GTG & GCA & GCT & $\mathrm{CCC}$ & AGA & $\mathrm{T} / \mathrm{GG}$ \\
\hline $\mathrm{F} 105 \mathrm{~V}_{\mathbf{H}}$ & $-\cdots$ & --- & $\cdots$ & $\cdots$ & -- & - - & $\cdots$ & $\cdots$ & $\ldots$ & $\cdots$ & $\cdots$ & $\cdots$ & $\cdots$ & & 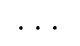 & \\
\hline Ab26: & $\ldots$ & $\ldots$ & $\ldots$ & $\ldots$ & $\ldots$ & $\ldots$ & $\ldots$ & $\ldots$ & $\ldots$ & $\ldots$ & $\ldots$ & $\ldots$ & $\ldots$ & $\ldots$ & $\ldots$ & . \\
\hline 268-D: & $\cdots$ & - - & -- & $\begin{array}{c}-- \\
1\end{array}$ & $\cdots$ & - - & $\cdots$ & -- & - - & $-\cdot$ & $\cdots$ & $\cdots$ & $\begin{array}{l}\cdots \\
10\end{array}$ & -- & -- & --- \\
\hline $\mathrm{V}_{\mathbf{H}} 71-4:$ & GTC & CTG & TCC & CAG & GTG & CAG & CTG & CAG & GAG & TCG & GGC & $\mathrm{CCA}$ & GGA & CTG & GTG & AAG \\
\hline F105V & $\ldots$ & $\ldots$ & $\ldots$ & $\ldots$ & $\ldots$ & $\ldots$ & $\ldots$ & $\ldots$ & $\ldots$ & $\ldots$ & $\ldots$ & $\ldots$ & $\ldots$ & $\cdots$ & $\ldots$ & $\cdots$ \\
\hline Ab26: & $\ldots$ & $\ldots$ & $\ldots$ & $\ldots$ & $\ldots$ & $\ldots$ & $\ldots$ & $\ldots$ & $\ldots$ & $\ldots$ & $\ldots$ & $\ldots$ & $\ldots$ & $\ldots$ & $\ldots$ & $\ldots$ \\
\hline 268-D: & -- & $\cdots$ & -- & $\ldots$ & $\ldots$ & $\ldots$ & $\begin{array}{l}\text { T. } \\
20\end{array}$ & $\ldots$ &. $\mathrm{T}$. & $\ldots$ & $\ldots$ & $\ldots$ & $\ldots$ & $\ldots$ & $\ldots$ & $\ldots$ \\
\hline$V_{H} 71-4:$ & $\mathrm{CCT}$ & TCG & GAG & ACC & CTG & TCC & CTC & ACC & TGC & ACT & GTC & $\mathrm{TCT}$ & GGT & GGC & TCC & GTC \\
\hline $\mathrm{F} 105 \mathrm{~V}_{\mathrm{H}}:$ & $\cdots$ & $\ldots$ & $\cdots$ & $\cdots$ & $\cdots$ & $\cdots$ & $\ldots$ & $\ldots$ & $\cdots$ & $\cdots$ & $\cdots$ & $\cdots$ & $\ldots \mathrm{A}$ & $\cdots$ & $\cdots$ & A. . \\
\hline Ab26: & $\ldots$ & $\ldots \mathrm{A}$ & C. . & $\ldots$ & $\ldots$ & $\ldots$ & $\ldots$ & $\ldots \mathrm{T}$ & $\ldots$ & $\ldots$ & $\ldots$ & $\ldots$ & $\ldots$ & $\ldots$ & $\ldots$ & A. . \\
\hline 268-D: & 30 & $\ldots$ & $\ldots$ & $\cdots$ & $\stackrel{\mathrm{CDR}}{\mathrm{C}}$ & $\cdots$ & $\ldots$ & $\cdots$ & $\ldots$ & $\ldots$ & $\ldots$ & $\ldots$ & $\cdots$ & 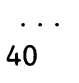 & C. . & A. . \\
\hline$V_{\mathbf{H}} 71-4:$ & AGT & $* * *$ & $* * *$ & AGT & $* * *$ & TAC & TAC & TGG & AGC & TGG & ATC & CGG & CAG & CCC & $\mathrm{CCA}$ & GGG \\
\hline F105V $V_{H}:$ & $\cdots$ & $\ldots$ & $\ldots$ & $\ldots$ & $\ldots$ & C. . & $\ldots$ & $\ldots$ & $\ldots$ & $\ldots$ & $\ldots$ & $\ldots$ & $\ldots$ & T. & $\ldots$ & $\ldots$ \\
\hline Ab26: & $\cdots$ & $\ldots$ & $\ldots$ & $\ldots$ & GGT & G.T & $\ldots$ & $\ldots$ & $\ldots$ & $\ldots$ & $\ldots$ & $\ldots C$ & $\ldots$ & A. & $\ldots$ & $\ldots$ \\
\hline 268-D: & A. & $* * *$ & $* * *$ & A. & $* * *$ & GC. & $\ldots$ & 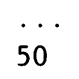 & . CA & & $\cdots$ & DA & $\cdots$ & $\cdots$ & $\ldots$ & \\
\hline$V_{H} 71-4:$ & AAG & GGA & CTG & GAG & TGG & ATT & GGG & TAT & ATC & TAT & TAC & AGT & GGG & AGC & $\mathrm{ACC}$ & AAC \\
\hline $\mathrm{F} 105 \mathrm{~V}_{\mathrm{H}}$ : & $\cdots$ & $\ldots$ & $\ldots$ & C. . & $\cdots$ & $\ldots$ & $\ldots \mathrm{A}$ & $\ldots$ & $\ldots$ & $\ldots C$ & $\ldots$ & $\ldots$ & $\ldots$ & $\cdots$ & $\cdots$ & $\cdots$ \\
\hline Ab26: & $\ldots$ & $\ldots \mathrm{C}$ & $\ldots$ & $\ldots$ & $\ldots$ & $\ldots$ & $\ldots$ & $\ldots C$ & $\ldots \mathrm{A}$ & $\ldots$ & $\ldots$ & $\ldots$ & $\ldots$ & $\ldots$ & $\ldots$ & $\ldots$ \\
\hline 268-D: & $\ldots$ & $\begin{array}{l}\ldots G \\
60\end{array}$ & $\ldots \mathrm{A}$ & $\ldots$ &. $\mathrm{AC}$ & C. . & $\ldots \mathrm{A}$ & $\ldots$ & G. . & $\ldots$ & C.T & $\begin{array}{l}\text {.C. } \\
70\end{array}$ & $\ldots \mathrm{A}$ & GT. & $\ldots$ & $\ldots$ \\
\hline $\mathrm{V}_{\mathbf{H}} 71-4:$ & TAC & AAC & $\mathrm{CCC}$ & TCC & CTC & AAG & AGT & CGA & GTC & ACC & ATA & TCA & GTA & GAC & ACG & TCC \\
\hline $\mathrm{F} 105 \mathrm{~V}_{\mathrm{H}}$ : & $\ldots$ & G. & $\ldots$ & $\ldots$ & $\cdots$ & $\cdots$ & $\cdots$ & $\ldots$ & $\ldots$ & $\ldots$ & $\ldots$ & $\ldots$ & $\ldots$ & $\ldots G$ & $\cdots$ & $\cdots$ \\
\hline Ab26: & $\ldots$ & $\ldots$ & $\ldots$ & $\ldots$ & $\ldots$ & $\ldots$ & $\ldots$ & $\ldots$ & $\ldots \mathrm{T}$ & G. . & $\ldots$ & $\ldots$ & $\ldots G$ & $\ldots$ & $\ldots$ & $\ldots \mathrm{T}$ \\
\hline 268-D: & $\ldots$ & $\ldots \mathrm{T}$ & $\cdots$ & $\ldots$ & $\ldots$ & . & $\ldots \mathrm{C}$ & $\ldots \mathrm{G}$ & C. . & $\ldots$ & $\ldots$ & A. . & A. . & $\ldots$ & $\ldots$ & $\ldots$ \\
\hline$V_{H} 71-4:$ & AAG & AAC & CAT & TCC & TCC & CTG & AAG & CTG & AGC & TCT & GTG & ACC & GCT & GCG & GAC & ACG \\
\hline$F 105 V_{H}:$ & $\cdots$ & $\cdots$ & $\cdots$ & $\cdots$ & $\cdots$ & $\cdots$ & $\cdots$ & $\cdots$ & . C. & $\cdots$ & A. . & $\cdots$ & $\cdots$ & $\cdots$ & $\cdots$ & $\cdots$ \\
\hline Ab26: & $\ldots$ & $\ldots$ & $\cdots$ & $\ldots$ & $\cdots$ & $\cdots$ & $\cdots$ & $\cdots$ & $\cdots$ & $\cdots$ & $\cdots$ & $\cdots$ & $\cdots$ & $\cdots$ & $\cdots$ & $\cdots$ \\
\hline 268-D: & . G. & $\ldots \mathrm{G}$ & 9 & $\ldots \mathrm{A}$ & $\ldots$ & $\ldots C$ &. $\mathrm{GC}$ & $\ldots$ & . AG &. $\mathrm{T}$. & $\ldots$ & $\ldots$ & $\ldots$ & $\ldots$ & $\ldots$ & T. . \\
\hline $\mathrm{V}_{\mathrm{H}} 71-4:$ & GCC & GTG & TAT & TAC & TGT & GCG & AGA & & & & & & & & & \\
\hline F105V & $\cdots$ & $\cdots$ & $\cdots$ & $\cdots$ & $\cdots$ & $\ldots$ & C. . & & & & & & & & & \\
\hline Ab26: & $\cdots$ & $\cdots$ & $\ldots$ & $\cdots$ & $\cdots$ & $\ldots$ & . C. & & & & & & & & & \\
\hline 268-D: & $\ldots$ & $\ldots A$ & $\ldots$ & $\ldots \mathrm{T}$ & $\ldots$ & $\ldots$ & $\ldots$ & & & & & & & & & \\
\hline
\end{tabular}

B. Amino Acid Sequence Comparison of $F 105 V_{H}$ to Somatic Rearranged $V_{H} 71-4$ Genes

\begin{tabular}{|c|c|c|c|c|c|c|c|c|c|c|c|c|c|c|c|c|c|c|}
\hline & -19 & & & & & & & & & & & & 1 & & & & 10 & \\
\hline$V_{H} 71-4$ & M K & & L W & $F$ & F L & L L & L & $\mathrm{V}$ A & A & $\mathrm{P} R$ & $\mathrm{~W}$ & V L S & $\mathrm{Q} \mathrm{V}$ & Q L Q & E S & G & $P G$ & L V \\
\hline $\mathrm{F} 105 \mathrm{Vh}$ & $-\quad-$ & - & $-\quad-$ & - & . . & . . & . & $\cdot$ & . & . . & . & . . . & . . & . . . & . . & . & . . & . \\
\hline Ab26 & . & . & . & . & . & . & . & · & . & . . & . & . . . & $\cdot \cdot$ & & . & . & . & . \\
\hline 268-D & - & - & - & - & & $\begin{array}{l}-- \\
20\end{array}$ & - & - & - & - & - & $\begin{array}{c}-- \\
30\end{array}$ & $\cdot \underset{\mathrm{CDR}}{\cdot}$ & & $\mathrm{V}$. & . & . & . \\
\hline$V_{H} 71-4$ & K P & $S \mathrm{E}$ & $\mathrm{E} T$ & $\mathrm{~L}$ & S L & $\mathrm{L} T$ & C $\mathrm{T}$ & $\mathrm{T} \mathrm{V}$ & $\mathrm{S}$ & G G & 5 & $\mathrm{~V} S *$ & $* \mathrm{~S} *$ & $* \mathrm{Y} \mathrm{Y}$ & W S & W I & R & Q \\
\hline F105Vh & . & . & . & . & . & . . & . & . . & . & . . & . & I . * & & * H. &. & . . & . & . \\
\hline Ab26 & . & & Q & . & . & . & . & . & . & . & . & I. * * & $* . \mathrm{C}$ & $\mathrm{G}$ & . . & . & . & . \\
\hline 268-D & 40 & . & . & . & . & . & . & & . & & $\mathrm{P}$ & $\begin{array}{l}\text { I N * } \\
\text { CDR2 }\end{array}$ & $\begin{array}{l}* \mathrm{~N} \\
60\end{array}$ & * A & $\cdot \mathrm{T}$ & . & . & 70 \\
\hline$V_{H} 71-4$ & P P & G & K G & $\mathrm{L}$ & & W I & G & Y I & $\mathrm{Y}$ & Y S & $G$ & $\mathrm{~S} T \mathrm{~N}$ & $\mathrm{YN}$ & $P \quad S \quad L$ & $\mathrm{~K} \mathrm{~S}$ & R & $\mathrm{V} T$ & I $\mathrm{S}$ \\
\hline F105Vh & S. & . & . & . & Q & . & . & & . & & & . . . & . $\mathrm{S}$ & & & . & & \\
\hline Ab26 & $\mathrm{H}$. & . & . $\cdot$ & . & . & i i & $\cdot$ & $\cdot \dot{\mathrm{y}}$ & $\cdot$ & $\dot{H} \cdot$ & . & $\cdot{ }^{\mathrm{V}} \cdot \mathrm{Y}$ & . & $\cdot \cdot$ & & . & . A & $\cdot \dot{T}$ \\
\hline 268-D & . . & & & . & & $\begin{array}{l}Y \\
\end{array}$ & & & & & & $v$. & & & & & & \\
\hline
\end{tabular}


80

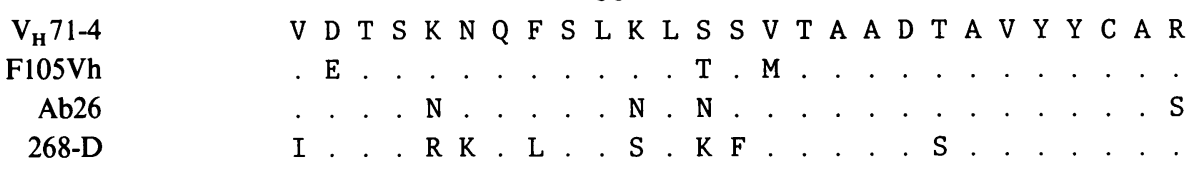

Dashes after F105 represent primer annealing sequences. Dashes after 268-D represent sequences that are not reported (29).

and 268-D, there are 19 and 42 nucleotide changes, respectively. In all of these examples, nucleotide changes are scattered in both the CDR and FR regions. All three antibodies have the guanosine to adenosine change in amino acid position 29 as does F105. Table III, $B$ shows the corresponding amino acid changes in these three mAbs. For antibodies Ab26 and 268-D there are 11 and 23 amino acid changes, respectively, compared with F105, which has 8 changes. The only change shared by three antibodies is valine to isoleucine in position 29 .

Analysis of the F105 $D_{H}$ gene encoding CDR3. The $\mathrm{D}_{\mathrm{H}}$ portion in $\mathrm{V}_{\mathrm{H}}-\mathrm{D}_{\mathrm{H}}-\mathrm{J}_{\mathrm{H}}$ structure corresponds to the CDR3 of $\mathrm{H}$ chain (41). Over 20 human germ line genes have been identified and it is estimated that the total number of $D_{H}$ genes is $\sim 30$ (42). As shown in Table IV, A, the F105 $D_{H}$ region appears to be composed of a D-D fusion product (43-46). A seven-nucleotide sequence in the center of the $F 105 D_{H}$ gene is identical to the germ line $\mathrm{D}_{\mathrm{H}}$ gene $d l r 4$. This region of identity is immediately flanked on its $5^{\prime}$ end by an additional two of three nucleotides that are identical when compared with $d l r 4$. The additional 5 ' nucleotides found in $\mathrm{F} 105 \mathrm{D}_{\mathrm{H}}$ that are rich in deoxyguanosines and deoxycytosines probably represent ran- dom "N segment" nucleotide additions since these are the favored nucleotides of the enzyme terminal deoxynucleotidyltransferase (47). Examination of the $3^{\prime}$ end of the F105 $D_{H}$ region shows that 11 of 13 nucleotides are identical to the da4/ dal germ line gene. The 3 ' end of this nucleotide sequence may extend into the $5^{\prime}$ end of the $J_{\mathbf{H}}$ region, the precise boundary of which is difficult to define accurately because of the identity with the da4/da1 germ line $D_{H}$ gene. Since both of these $D_{H}$ genes are in the same transcriptional orientation, rearrangement probably occurred by deletion rather than by inversion (43).

A GeneBank search for other rearranged human heavy chain genes that have nucleotide sequence homologies with the $F 105 D_{H}$ gene revealed two rearranged genes (L17 and L37). These have a relatively short $D_{H}$ segment ( $\sim 24$ nucleotides) compared with F105 but contain near their $5^{\prime}$ end the same 12 nucleotide "core" that is identical to 12 nucleotides at the 3 ' end of the F105 $D_{H}$ gene (Table IV, B) (48). The finding that three unrelated antibodies have this same da4/da1-related segment suggests that this sequence is related to a germ line gene and that the two base changes, both guanosine to adenosine

Table IV. F105 Heavy Chain D Region Sequence Comparisons

A. Comparison of $F 105 D_{H}$ gene with human germ line $D_{H}$ region genes

\begin{tabular}{|c|c|c|}
\hline dlr4 & AGGATATTGTAGTAGTACCAGCTG & CTATGCC \\
\hline F105 & \multicolumn{2}{|c|}{$\overline{\mathrm{G} g c c c c \overline{\mathrm{GT}} g \overline{\mathrm{CCAGCTG}}} t \operatorname{ctt} \overline{\mathrm{CTA}} \mathrm{s} \overline{\mathrm{G} g} \mathrm{~g} g a c t a c$} \\
\hline F105 & ggcccegtgccagctgt & tt $\underline{\text { TACgGTgACTAC }}$ \\
\hline & & GACTACAGTAACTAC \\
\hline & & GACTACAGTAACTAC \\
\hline
\end{tabular}

Nucleotide sequences of three human germ line $D_{H}$ genes dlr4, da4, and dal (42). Underlined nucleotides show identity between F105 D region and a known germ line $D_{H}$ gene.

B. Comparison of the F105 and L17/L37 $\mathrm{D}_{\mathrm{H}} / \mathrm{J}_{\mathrm{H}}$ boundaries

\begin{tabular}{|c|c|c|c|c|c|c|c|c|c|c|c|c|c|}
\hline Kabat Position & 95 & 96 & 97 & 98 & 99 & 100 & A & B & $\mathrm{C}$ & D & $\mathbf{E}$ & & \\
\hline F105 Amino acid & Gly & Pro & Val & Pro & Ala & $\mathrm{Val}$ & Phe & Tyr & Gly & Asp & Tyr & & \\
\hline F105 Nucleotide & GGC & $\operatorname{ccc}$ & GTG & CCA & GCT & GTC & TTC & $\underline{\mathrm{TAC}}$ & GGT & GAC & TAC & & \\
\hline L17/L37 Nucleotide & & & & & & gg & $g \quad a g$ & $\underline{\mathrm{T}} \underline{\mathrm{ACC}}$ & $\underline{G} \quad \underline{G T}$ & $\underline{\mathrm{ACT}}$ & $\underline{\mathrm{T}} \underline{\mathrm{ACg}}$ & gga & gat \\
\hline L17/L37 Amino acid & & & & & & Gl & $\mathrm{Se}$ & Th: & $\mathrm{Va}$ & Thr & Thr & Gly & Asp \\
\hline Kabat Position & & & & & & 96 & 97 & 98 & 99 & 100 & A & B & $\mathrm{C}$ \\
\hline
\end{tabular}

L17/L37 are rearranged $D_{H}$ region gene that are derived from tonsillar lymphocytes that express the $V_{H} I$ related G6 cross-reactive idiotype (48). Underlined nucleotides show identity between F105 D region and the L17/L37 D region genes. 
Table V. Comparison of F105 $\mathrm{J}_{\mathrm{H}}$ to Germ Line $\mathrm{J}_{\mathrm{HS}}$

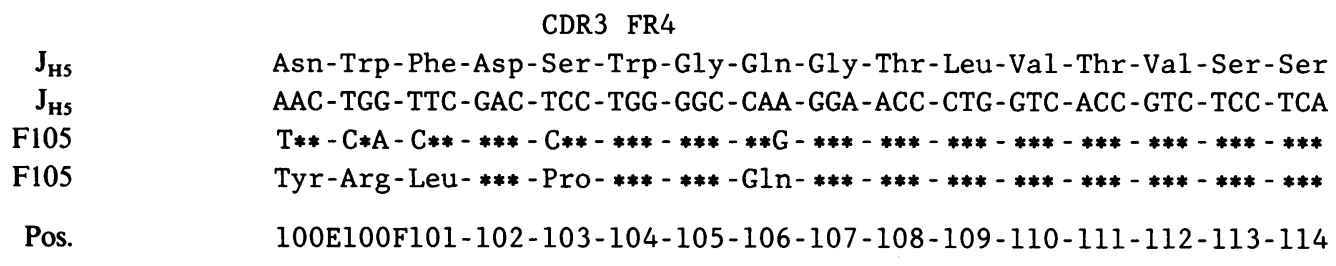

Four somatic mutations that are clustered at the $5^{\prime}$ end of $\mathrm{F} 105 \mathrm{~J}_{\mathrm{H}}$ in positions $100 \mathrm{E}, 100 \mathrm{~F}, 101$, and 103 result in substitution mutations whereas the fifth somatic mutation in position 106 is silent.

changes, may represent allelic differences in the da4/da1 germ line genes rather than somatic mutations. Table IV, B also demonstrates that F105 and L17/L37 use different reading frames for the 12 identical nucleotides, which results in different amino acids for this portion of CDR3 (48). This observation is in agreement with several studies that show that all of the three coding frames appear to be used equally in the human $(42,45)$. However, preferential use of one reading frame has been demonstrated with anti-DNA antibodies (49) and with certain germ line $\mathrm{D}_{\mathrm{H}}$ genes (45).

Analysis of the F105 $J_{H}$ region gene. Comparison of the $\mathrm{F} 105 \mathrm{~J}_{\mathrm{H}}$ region with the six human $\mathrm{J}_{\mathrm{H}}$ germ line genes reveals greatest sequence similarity with $J_{H_{5}}\left(\right.$ Table V). The F105 $J_{H}$ region differs by six nucleotides from that of $\mathrm{J}_{\mathrm{H} 5}$. Five of these differences are clustered at the $5^{\prime}$ end of the $J_{H}$ gene. These five differences result in four amino acid changes. Nonconservative changes occur at positions $100 \mathrm{E}, 100 \mathrm{~F}, 101$, and 103. The sixth nucleotide change, occurring in amino acid position 106, which lies outside of CDR3, is silent. It is possible that the amino acid corresponding to position $100 \mathrm{E}$ in $\mathrm{J}_{\mathrm{H} 5}$ is deleted in $\mathrm{F} 105 \mathrm{~J}_{\mathrm{H}}$.

F105 heavy chain shares the CDR2 idiotope HV2a. Silverman and Carson (37) used peptide antisera raised against consensus peptides from the first framework (FR1) and second CDR region (CDR2) of human $V_{H}$ IV heavy chains to make heavy chain class assignments for cold agglutinin and rheumatoid factor antibodies $(37,50)$. The CDR2 consensus peptide HV2a for these antibodies could not distinguish among three different $V_{H} I V$ germ line genes (V71-2, V71-4, and V79)(37). The results demonstrated that both cold agglutinin and a subgroup of rheumatoid factor heavy chains both reacted with FR1 antibodies but only cold agglutinin antibodies reacted with anti- $\mathrm{V}_{\mathbf{H}} 4-\mathrm{HV} 2 \mathrm{a}$ antisera. Fig. 1 illustrates ELISA experiments with F105 and the cold agglutinin IgM ODO. The anti$\mathrm{V}_{\mathrm{H}}$ 4-FR1 antisera reacts strongly with both $\mathrm{F} 105$ and IgM ODO whereas anti- $\mathrm{V}_{\mathrm{H}} 3-\mathrm{FR} 1$ antisera shows only background activity compared with the unrelated rabbit antiformyl-MetLeu-Phe antisera. F105 also reacts with anti-VH4-HV2a, albeit weakly, and this binding is inhibited by preincubation of antiVH4-HV2a with VH4-HV2a peptide and to a lesser extent with the closely related $\mathrm{VH} 4-2 \mathrm{c}$ peptide. This result indicates that the $\mathrm{F} 105 \mathrm{~V}_{\mathbf{H}}$ is structurally more closely related to the cold agglutinin heavy chains than to the rheumatoid factor heavy chains.

F105 light chain $V_{\text {kappa }}$ gene is derived from germ line Humvk325 germ line gene. For the analysis of the F105 kappa chain, the source of mRNA, method of first strand cDNA synthesis, and conditions for amplification by PCR were identical
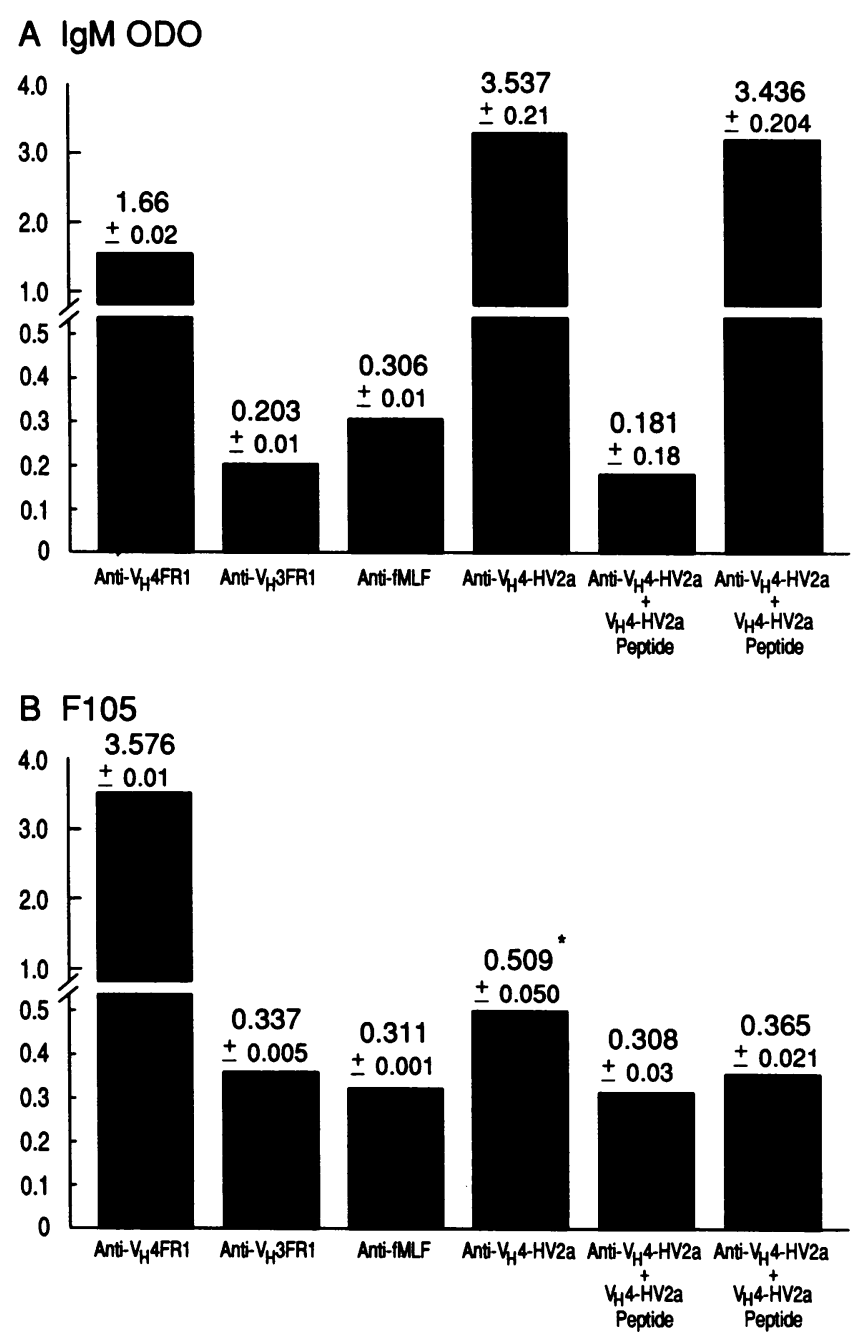

Figure 1. ELISA analysis of F105 and IgM ODO. $150 \mathrm{ng} /$ well of F105 or IgM ODO were incubated overnight on ELISA plates. After blocking with TBS-T with $1 \%$ BSA, the plates were incubated with various rabbit anti-peptide antisera (1:1500 final dilution) that recognize $V_{H}$ III or IV framework or $V_{H}$ IV CDR2 determinants (37). $A$ rabbit antisera raised against an unrelated peptide served at a negative control (rabbit antiformyl Met-Leu-Phe/BSA). In some cases CDR2 peptides were preincubated at $1 \mu \mathrm{g} / \mathrm{ml}$ with anti-CDR2 peptide antisera for $1 \mathrm{~h}$ at room temperature before addition to the plate. Bound rabbit antibody was detected with affinity column-purified, alkaline phosphatase-coupled goat anti-rabbit IgG that had been absorbed with human serum. Absorption at $405 \mathrm{~nm}$ was recorded. Data represent mean of triplicate determinations \pm SD. ${ }^{*} P<0.01$ compared with anti- $\mathrm{V}_{\mathrm{H}} 3 \mathrm{FR} 1$ or anti- $\mathrm{fMLF}$ using Student's two-tailed $t$ test. ( $A$ ) IgM ODO-coated plates; (B) F105-coated plates. 
to those used for the heavy chain. The degenerate $V_{\text {kappa }}$ and $\mathrm{J}_{\text {kappa }}$ primers were initially used to amplify by PCR an $\sim 350$ nucleotide fragment. This is the expected molecular weight of the rearranged kappa light chain gene. This amplified DNA was inserted into the pSL1180 plasmid. Subsequent to the identification of the germ line $\mathrm{V}_{\text {kappa }}$ gene, the cDNA was reamplified using primers that recognize the leader and kappa chain constant regions to obtain unbiased DNA sequence information of the FR1 and $J_{\text {kappa }}$ regions.

DNA sequence analysis revealed that the rearranged F105 $V_{k}$ gene is derived from a member of the $V_{k}$ III subgroup gene family (33). The $V_{k}$ III subgroup can be further subdivided into sub-subgroups, one of which is the $V_{k}$ IIIb sub-subgroup. F105 shares the greatest sequence similarity with the $V_{k}$ IIIb germ line gene Humvk325 (97.7\%, 343/351 nucleotides) ( Table VI, A). There are a total of nine nucleotide changes in F105 $\mathrm{V}_{\mathrm{k}}$ compared with Humvk325 ( Table II). Two of the changes, which are both transversions, are located in the framework regions FR1 and FR3. Seven additional changes, including four transitions and three transversions, are located in CDR 1 (one) and CDR3 (six).

At the amino acid level, only two of the nucleotide changes result in a silent mutations. Of the remaining seven nucleotide changes, two changes occur in framework regions and five occur in the CDR regions (Table II and Table VI, B). The two framework changes include a nonconservative change at position 15 in FR 1 and a conservative change at position 78 in FR3. In the CDR regions, one change occurs with a nonconservative substitution at position 31 in CDR1. There are three nonconservative amino acid changes in CDR3 in positions 92, 94 , and 95 . The change at position 95 (proline to valine) is the result of two individual point mutations that occur in one codon. The ratio of substitution to silent mutations is $7: 2$ and these changes occur in a FR/CDR ratio of 2:7. This pattern of changes is in marked contrast to the pattern of changes observed for the $\mathrm{F} 105 \mathrm{~V}_{\mathrm{H}}$ sequence where the ratio of substitution to silent mutations is $2: 1$ and the substitution mutations occur in a FR/CDR ratio of 3:1 (Table II).

Analysis of the F105 $\mathrm{J}_{k}$ region gene. The $\mathrm{F} 105 \mathrm{~J}_{\mathbf{k}}$ region is most similar to the germ line $J_{k 2}$ gene (Table VI, A). The codon at position 96 is formed by the recombination of $V_{k}$ and $J_{k}$ and has a single nucleotide change that results in the nonconservative replacement of tyrosine for cysteine. A silent thymidine to adenosine change also occurs at position 108, otherwise the $\mathrm{F} 105 \mathrm{~J}_{\mathbf{k}}$ gene is in $\mathrm{J}_{\mathbf{k} 2}$ germ line configuration.

Comparative analysis of the F105 rearranged kappa chain with other rearranged Humvk325-related kappa chains. Rheumatoid factor antibodies are typically IgMk antibodies and are directed against IgG antibodies. Many IgMk rheumatoid factors use the Humvk325 gene in the germ line unmutated configuration $(51,52)$ and several also use the $J_{k 2}$ gene in unmutated form (51) as in F105. Table VI, B compares the amino acid and nucleotide sequence of the rearranged F105 kappa chain to the kappa chain of the closely related IgMk rheumatoid factor $n e u$. The neu kappa chain is similar to F105 with two identical point mutations in positions 31 and 96 . The latter change occurs as a result of an uncommon $\mathrm{V} / \mathrm{J}$ joining event.

\section{Discussion}

This study reports the primary nucleotide and deduced amino acid sequence analysis of the human antibody F105 that is directed toward the conformationally sensitive CD4-binding domain of gp120. The results show that the F105 antibody is created by rearrangement of the $\mathrm{V}_{\mathrm{H}}$ 71-4 and Humvk325 germ line variable region genes along with selected individual point mutations in the rearranged genes.

The mutational pattern in the rearranged $V_{H}$ and $V_{L}$ genes is indicative of an antigen-driven process. For F105 $V_{H}$ the ratio of substitution to silent mutations is $2: 1$. These substitution mutations occur in a FR/CDR ratio of $3: 1$. This type of change involving a high number of amino acid substitutions in the FR regions has been attributed to stochastic rather than selective forces since antigen-driven selective forces would be expected to impose higher selection pressure on the CDR regions. It is possible that selection has occurred but has acted to retain CDR 1 and 2 in near germ line configuration, whereas more divergence is allowed in the FR regions where these residues may play a role in antigen binding (53). It is also possible that these FR mutations may play a role in network regulation, i.e., are selected by necessity of idiotypic regulation in the antigp120 response (54). However, changes in the $V_{H}$ gene segment must be considered in the context of the overall selection forces that act on the heavy chain. The power of antigen selection can make D-D fusions, a relatively rare event in B cell development, which occur at a lower frequency than normal joining, biologically significant (43). In addition, heavy chain selection may be biased to changes in CDR3 since four of five amino acid changes occur in the $\mathrm{J}_{\mathrm{H} 5}$ gene and these changes are concentrated in the $5^{\prime}$ end of the gene, which contributes to the formation of CDR3 ( Table V).

For the F105 kappa chain, the ratio of substitution to silent mutations is 7:2 and these mutations occur in a FR/CDR ratio of 2:7. This is in marked contrast to the mutational pattern seen with $\mathrm{F} 105 \mathrm{~V}_{\mathrm{H}}$ ( Table III) and strongly supports the notion that these somatic changes are the result of an antigen-driven process. Most notable are the higher number of mutations in CDR3 than are generally found when compared with cloned Humvk325-derived light chain genes from patients with chronic lymphocytic leukemia (55), small cell non-Hodgkin's lymphoma (56), monoclonal rheumatoid factors (51), and Sjögren's syndrome (57). These somatic mutations could reflect the chronic B cell activation that occurs both in the regional lymph nodes and peripheral blood of patients with AIDS (58).

The F105 $\mathrm{V}_{\mathrm{H}}$ gene is derived from a member of the $\mathrm{V}_{\mathrm{H}}$ IV gene family, $V_{H}$ 71-4. This is a relatively small family with $\sim 10$ members. The expression of $V_{H}$ IV genes in humans has been described only recently; indeed, the heavy chain families, $\mathrm{V}_{\mathbf{H}} \mathrm{IV}, \mathrm{V}$, and VI were identified only in the last five years (35). Expressed $V_{H}$ IV genes have been found at an unexpectedly high frequency in human autoantibodies $(28,40,53,59-$ $61)$. Only a few of these antibodies have been shown to use the $V_{H}$ 71-4 germ line gene (Table $\left.V\right)(59,62)$. The most studied of the $V_{H}$ IV-derived heavy chain genes include the cold agglutinin and rheumatoid factor antibodies. Several laboratories have determined that cold agglutinins use the $\mathrm{V}_{\mathbf{H}}$ IV 2-1 germ line gene segment $(53,62-64)$ whereas a subgroup of autoantibodies of the IgM anti-IgG type (rheumatoid factors) use members of a $V_{H}$ IV gene family that is serologically distinct from the cold agglutinin $V_{H}$ IV 2-1-derived genes (50). The molecular characterization of these $V_{H}$ IV rheumatoid factor heavy chains has not been reported. Our studies demonstrate that the VH4-HV2a idiotope is expressed, albeit weakly, on the 
A. Nucleotide sequence comparison of $\mathrm{F} 105 \mathrm{~V}_{\mathrm{kappa}}$ with germ line gene Humvk325

\begin{tabular}{|c|c|c|c|c|c|c|c|c|c|c|c|c|c|c|c|c|}
\hline \multirow{2}{*}{ vk325: } & \multicolumn{5}{|l|}{-20} & \multicolumn{11}{|c|}{-10} \\
\hline & ATG & GAA & $\mathrm{ACC}$ & $\mathrm{CCA}$ & GCG & CAG & CTT & CTC & TTC & CTC & СTG & CTA & CTC & TGG & CTC & $\mathrm{CCA}$ \\
\hline F105Vk: & - - & - - & $\cdots$ & $\cdots$ & $-\cdot$ & - - & $\ldots$ & $\ldots$ & $\ldots$ & $\ldots$ & $\ldots$ & $\ldots$ & $\ldots$ & $\ldots$ & $\ldots$ & $\ldots$ \\
\hline & & & & & 1 & & & & & & & & & 10 & & \\
\hline vk325: & GAT & ACC & ACC & GGA & GAA & ATT & GTG & TTG & ACG & CAG & TCT & $\mathrm{CCA}$ & GGC & ACC & CTG & TCT \\
\hline $\mathrm{F} 105 \mathrm{~V}_{\mathrm{k}}$ : & $\cdots$ & $\cdots$ & $\cdots$ & $\cdots$ & $\cdots$ & $\ldots$ & $\cdots$ & $\ldots$ & $\cdots$ & $\cdots$ & $\cdots$ & $\cdots$ & $\ldots$ & $\cdots$ & $\cdots$ & $\ldots$ \\
\hline & & & & & & & & 20 & & & & & & CDR1 & & \\
\hline vk325: & TTG & TCT & $\mathrm{CCA}$ & GGG & GAA & AGA & GCC & ACC & CTC & $\mathrm{TCC}$ & TGC & $\underline{\mathrm{AGG}}$ & GCC & AGT & $\mathrm{CAG}$ & AGT \\
\hline F105Vk: & $\cdots$ & $\ldots$ & G. . & $\ldots$ & $\ldots$ & $\ldots$ & $\cdots$ & $\ldots$ & $\cdots$ & $\cdots$ & $\ldots$ & $\ldots$ & $\cdots$ & $\ldots$ & $\ldots$ & $\ldots$ \\
\hline & & & 30 & & & & & & & & & & 40 & & & \\
\hline vk325: & GTT & $\mathrm{AGC}$ & AGC & AGC & TAC & TTA & GCC & TGG & TAC & CAG & $\mathrm{CAG}$ & AAA & $\mathrm{CCT}$ & GGC & CAG & GCT \\
\hline $\mathrm{F} 105 \mathrm{~V}_{\mathbf{k}}$ : & $\ldots$ & $\ldots$ & $\ldots$ & $\ldots G$ & $\ldots$ & $\ldots$ & $\cdots$ & $\ldots$ & $\ldots$ & $\cdots$ & $\ldots$ & $\ldots$ & $\ldots$ & $\ldots$ & $\ldots$ & $\ldots$ \\
\hline & & & & & & & 50 & & & $\mathrm{CDR} 2$ & & & & & & \\
\hline vk325: & $\mathrm{CCC}$ & AGG & CTC & СтC & ATC & TAT & GGT & GCA & TCC & AGC & AGG & GCC & $\mathrm{ACT}$ & GGC & ATC & $\mathrm{CCA}$ \\
\hline $\mathrm{F} 105 \mathrm{~V}_{\mathbf{k}}:$ & $\cdots$ & $\ldots$ & $\ldots$ & $\cdots$ & $\ldots$ & $\cdots$ & $\ldots$ & $\cdots$ & $\ldots$ & $\cdots$ & $\cdots$ & $\ldots$ & $\ldots$ & $\ldots$ & $\ldots$ & $\ldots$ \\
\hline & 60 & & & & & & & & & & 70 & & & & & \\
\hline vk325: & GAC & AGG & TTC & AGT & GGC & AGT & GGG & TCT & GGG & $\mathrm{ACA}$ & GAC & TTC & ACT & CTC & ACC & ATC \\
\hline $\mathrm{F} 105 \mathrm{~V}_{\mathbf{k}}$ & & & $\cdots$ & $\ldots$ & $\ldots$ & $\cdots$ & $\ldots$ & $\ldots$ & $\ldots$ & $\ldots$ & $\ldots$ & $\ldots$ & $\ldots$ & $\ldots$ & $\ldots$ & $\ldots$ \\
\hline & & & & & 80 & & & & & & & & & & 90 & \\
\hline vk325: & AGC & AGA & CTG & GAG & $\mathrm{CCT}$ & GAA & GAT & TTT & GCA & GGT & TAT & TAC & TGT & $\underline{\mathrm{CAG}}$ & $\mathrm{CAG}$ & TAT \\
\hline $\mathrm{F} 105 \mathrm{~V}_{\mathbf{k}}$ : & $\ldots$ & $\ldots$ & G. . & $\ldots$ & $\ldots$ & $\ldots$ & $\ldots$ & $\ldots$ & $\ldots$ & $\cdots$ & $\ldots$ & $\ldots$ & $\cdots$ & $\cdots$ & $\ldots \mathrm{A}$ & \\
\hline & & & $\mathrm{R} 3$ & & & & & & & & & & & & & \\
\hline vk325: & GGT & AGC & TCA & $\mathrm{CCT}$ & & & & & & & & & & & & \\
\hline $\mathrm{F} 105 \mathrm{~V}_{\mathrm{k}}$ : & A. & A. & $\ldots \mathrm{C}$ & $\overline{\mathrm{GT}}$. & & & & & & & & & & & & \\
\hline $\mathrm{J}_{\mathbf{k} \mathbf{2}}:$ & $\underline{\mathrm{TAC}}$ & $\mathrm{ACT}$ & TTT & GGC & CAG & GGG & $\mathrm{ACC}$ & AAG & CTG & GAG & ATC & AAA & CGT & & & \\
\hline F105: &. $\mathrm{G}$. & $\ldots$ & $\ldots$ & $\ldots$ & $\ldots$ & $\ldots$ & $\ldots$ & $\ldots$ & $\ldots$ & $\ldots$ & $\ldots$ & $\ldots$ & $\ldots \mathrm{A}$ & & & \\
\hline
\end{tabular}

B. Amino acid sequence comparison of $\mathrm{F} 105 \mathrm{~V}_{\mathrm{kappa}}$ with germ line Humvk325 and a related rearranged kappa chain

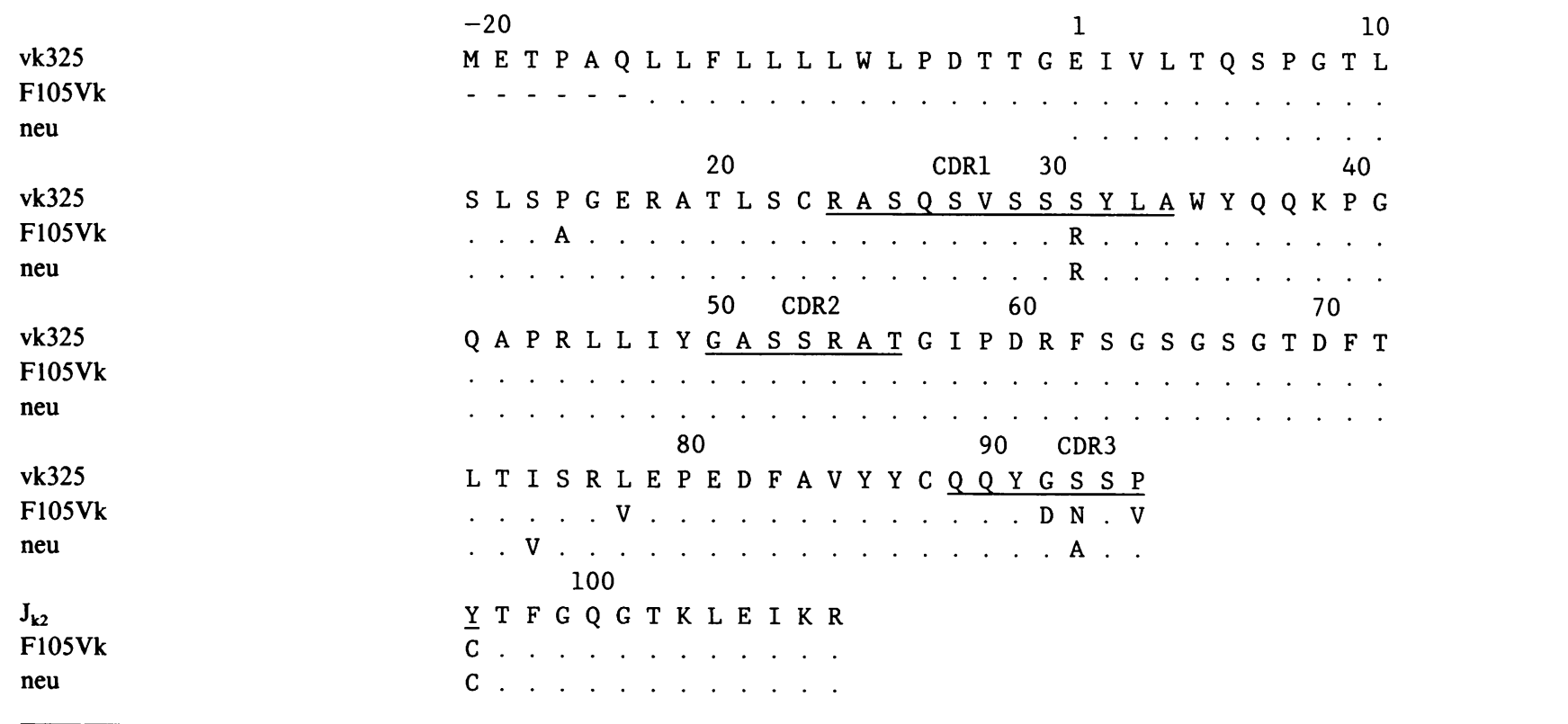


F105 heavy chain. The weak binding may be the result of the asparagine to serine substitution in position 60 . Accordingly, by this type of antiidiotypic analysis the $\mathrm{F} 105 \mathrm{~V}_{\mathrm{H}}$ is more closely related structurally to the $V_{H}$ IV heavy chains of anti-I cold agglutinin antibodies than to the $V_{H}$ IV heavy chains of the rheumatoid factor antibodies. However, in spite of this structural similarity, F105 displays neither cold agglutinin nor rheumatoid factor activity (data not shown).

Restricted heavy and light chain $\mathrm{V}$ gene use occurs in several autoimmune $(57,63,65)$ and infectious diseases (66-68). Restricted V gene use in response to gp 120 is highly suggested by several recent observations with antiidiotypic antibodies $(69,70)$, however, only limited anti-gp120 sequence data are available at present for comparison with F105. Andris et al. (29) recently reported the heavy chain nucleotide sequences of two human anti-gp120 V3 loop and two anti-gp41 mAbs that were produced by EBV transformation of peripheral blood cells of HIV-infected patients. Their analysis showed that one of the anti-V3 loop antibodies (268-D) (Table III) used the $V_{H}$ 71-4 germ line gene whereas the other anti-V3 loop antibody (257-D) used a $V_{H} V$ germ line gene $V_{H} 251$. Both of the antigp41 antibodies (120-16 and 98-6) used $V_{H}$ IV germ line genes, $V_{H}$ 71-2 and $V_{H}$ 2-1, respectively. The predominance of $V_{H}$ IV genes in these examples is evident. Additional sequence data will be required to identify any restricted use of $\mathrm{V}$ region genes.

The $\mathrm{V}$ region of the $\mathrm{F} 105$ light chain appears to be derived from the Humvk325 germ line gene and is a member of the VkIIIb sub-subgroup. The phenotypic marker of the human germ line gene Humkv325 is the 17.109 cross-reactive idiotype $(36,71,72)$ as defined by a murine $\mathrm{mAb}$ that was raised against human rheumatoid factor (73). The 17.109 cross-reactive idiotype is expressed by $\sim 2 \%$ of circulating IgM from normal adults (74). In addition to the aforementioned occurrence of Humkv325 light chains in monoclonal rheumatoid factors (51), in B cell malignancies, including chronic lympocytic leukemia (55) and small cell non-Hodgkin's lymphoma (56), and in lymphocytes from biopsy specimens of patients with primary Sjögren's syndrome (57), Humkv325 light chains have also been detected in non-rheumatoid factor paraproteins and in antibodies with anti-LDL, anti-intermediate filament, and anti-DNA histone activity $(51,52,72)$.

Whether HIV-1 infection and/or gp120 itself can directly or preferentially stimulate an immune response that uses Humvk325-derived $\mathrm{V}_{\mathrm{k}}$ genes is uncertain. Other viruses, most notably members of the herpes virus family have been implicated in such stimulation. The 17.109 cross-reactive idiotype is expressed by in vitro and in vivo EBV-infected B cells and, in the latter, IgM associated 17.109 cross-reactive idiotype was elevated in acute infection and later declined whereas IgG-associated 17.109 cross-reactive idiotype rose (75). The human anticytomegalovirus antibody EV1-15 has also been shown to use a $\mathrm{V}_{\mathbf{k}}$ IIIb light chain that is probably derived from Humvk325 (76). In the peripheral blood of HIV-infected patients with AIDS, resting B cells appear to be lacking, and there are both decreased numbers of partially activated cells and increased numbers of fully differentiated B cells (58). The polyclonal $B$ cell activation seen in these AIDS patients may be due to concomitant EBV or cytomegalovirus infections, which are often seen in these patients, or may be due to a direct effect of HIV (58). Whether this polyclonal B cell activation that is seen in HIV-infected patients is manifested by a increased frequency of 17.109 cross-reactive idiotype expression cannot be answered by the present study but represents an important avenue for future investigations.

The adult repertoire of antibody specificities is acquired in a developmentally programmed fashion (77). Schroeder et al. (77) and Kipps et al. (78) have demonstrated that rearranged $\mathrm{V}_{\mathrm{H}}$ 71-4 genes (V58P2 and V37P1) and the 17.109 cross-reactive idiotype are expressed in fetal tissue, respectively. Since the restricted use of $V_{H}$ genes may limit immunocompetence in fetal and neonatal life (77), it will be of importance to determine if the anti-gp 120 antibodies produced by these neonatal and pediatric $\mathrm{HIV}$-infected patients, in particular those antibodies that recognize determinants within the CD4 recognition site of gp120, use these same V region germ line genes with or without somatic mutations.

\section{Acknowledgments}

We thank Dr. Gregg J. Silverman, for his generous gift of rabbit peptide antisera and ODO IgM cold agglutinin antibody. We also wish to thank Dr. Walter Dzik, New England Deaconess Hospital for performing the cold agglutinin assays.

A portion of this work was funded by Centocor Inc. Wayne Marasco is supported by American Foundation for AIDS Research (0012529-RG) and the National Institutes of Health (K08-CA01507). Joseph Sodroski is supported by the Leukemia Society of America and the National Institutes of Health (AI31783).

\section{References}

1. Gallo, R. C., S. Z. Salahuddin, M. Popovic, G. M. Shearer, M. Kaplan, B. F. Haynes, T. J. Palker, R. Redfield, J. Oleske, B. Safai, et al. 1984. Frequent detection and isolation of cytopathic retroviruses (HTLV-III) from patients with AIDS and at risk for AIDS. Science (Wash. DC). 224:500-503.

2. Gartner, S., P. Markovits, D. M. Markovitz, M. H. Kaplan, R. C. Gallo, and M. Popovic. 1986. The role of mononuclear phagocytes in HTLV-III/LAV infection. Science (Wash. DC). 233:215-219.

3. Klatzmann, D., F. Barre-Sinoussi, M. T. Nugeyre, C. Dauguet, E. Vilmer, C. Griscelli, F. Brun-Vezinet, C. Rouzioux, J. C. Gluckman, J.-C. Chermann, et al. 1984. Selective tropism of lymphoadenopathy associated virus (LAV) for helper-inducer T lymphocytes. Science (Wash. DC). 225:59-63.

4. Langhoff, E., E. F. Terwilliger, H. J. Bos, K. H. Kalland, M. Poznansky, O. M. L. Bacon, and W. A. Haseltine. 1991. Replication of human immunodeficiency virus type 1 in primary dendritic cell cultures. Proc. Natl. Acad. Sci. USA. 88:7998-8002.

5. Patterson, S., and S. C. Knight. 1987. Susceptibility of human peripheral blood dendritic cells to infection by human immunodeficiency virus. J. Gen. Virol. 68:1177-1181.

6. Dalgleish, A. G., P. C. L. Beverley, P. R. Clapmam, D. H. Crawford, M. F. Greaves, and R. A. Weiss. 1984. The CD4(T4) antigen is an essential component of the receptor for the AIDS retrovirus. Nature (Lond.). 312:763-767.

7. Klatzmann, D., E. Champagne, S. Chamaret, J. Gruest, D. Guetard, T. Hercend, J.-C. Gluckman, and L. Montagnier. 1984. T-lymphocyte T4 molecule behaves as the receptor for human retrovirus LAV. Nature (Lond.). 312:767768.

8. Fauci, A. S., A. M. Macher, D. L. Longo, H. C. Lane, A. H. Rook, H. Masur, and E. P. Gelmann. 1984. Acquired immunodeficiency syndrome: epidemiologic, clinical, immunologic, and therapeutic considerations. Ann. Intern. Med. 100:92-99.

9. Haigwood, N., C. Barker, K. Higgins, P. Skiles, G. Moore, K. Mann, D. Lee, J. Eichberg, and K. Steimer. 1990. Evidence for neutralizing antibodies directed against conformational epitopes of HIV-1 gp120. Vaccines (Cold Spring Harbor). 90:313-320.

10. Steimer, K. S., C. J. Scandella, P. V. Skiles, and N. L. Haigwood. 1991. Neutralization of divergent HIV-1 isolates by conformation-dependent human antibodies to gp 120. Science (Wash. DC). 254:105-108.

11. Rusche, J. R., K. Javaherian, C. McDanal, J. Petro, D. L. Lynn, R. Grimaila, A. Langlois, R. C. Gallo, L. O. Arthur, P. J. Fischinger, et al. 1988. Antibodies that inhibit fusion of human immunodeficiency virus-infected cells bind a 24-amino acid sequence of the viral envelope, gp120. Proc. Natl. Acad. Sci. USA. 85:3198-3202.

12. Goudsmit, J., C. Debouck, R. H. Meloen, L. Smit, M. Bakker, D. M. 
Asher, A. V. Wolff, C. J. Gibbs, Jr., and D. C. Gajdusek. 1988. Human immunodeficiency virus type 1 neutralization epitope with conserved architecture elicits early type-specific antibodies in experimentally infected chimpanzees. Proc. Natl. Acad. Sci. USA. 85:4478-4482.

13. Palker, T. J., M. E. Clark, A. J. Langlois, T. J. Matthews, K. J. Weinhold, R. R. Randall, D. P. Bolognesi, and B. F. Haynes. 1988. Type-specific neutralization of the human immunodeficiency virus with antibodies to env-encoded synthetic peptides. Proc. Natl. Acad. Sci. USA. 85:1932-1936.

14. Kang, C.-Y., P. Nara, S. Chamat, V. Caralli, T. Ryskamp, N. Haigwood, R. Newman, and H. Kohler. 1991. Evidence for non-V3-specific neutralizing antibodies that interfere with gp 120/CD4 binding in human immunodeficiency virus 1-infected humans. Proc. Natl. Acad. Sci. USA. 88:6171-6175.

15. McKeating, J. A., J. Gow, J. Goudsmit, L. H. Pearl, C. Mulder, and R. A. Weiss. 1989. Characterization of HIV-1 neutralization escape mutants. AIDS (Phila.). 3:777-783.

16. Looney, D. J., A. G. Fisher, S. D. Putney, J. R. Rusche, R. R. Redfield, D. S. Burke, R. C. Gallo, and F. Wong-Stall. 1988. Type-restricted neutralization of molecular clones of human immunodeficiency virus. Science (Wash. DC). 241:357-360.

17. Ho, D. D., M. G. Sarngadharan, M. S. Hirsch, R. T. Schooley, R. T. Rota, R. C. Kennedy, T. C. Chanh, and V. L. Sato. 1987. Human immunodeficiency virus neutralizing antibodies recognize several conserved domains on the envelope glycoproteins. $J$. Virol. 61:2024-2028.

18. Nara, P. L., W. G. Robey, L. O. Arthur, D. M. Asher, A. V. Wolff, C. J. Gibbs, Jr., D. C. Gajdusek, and P. J. Fischinger. 1987. Persistent infection of chimpanzees with human immunodeficiency virus: serological responses and properties of reisolated viruses. J. Virol. 61:3173-3180.

19. Goudsmit, J., C. Thiriart, L. Smit, C. Bruck, and C. J. Gibbs. 1988 Temporal development of cross-neutralization between HTLV-III B and HTLVIII RF in experimentally infected chimpanzees. Vaccine. 6:229-238.

20. McDougal, J. S., J. K. A. Nicholson, G. D. Cross, S. Cort, M. S. Kennedy, and A. Mawle. 1986. Binding of the human retrovirus HTLV-III/LAV/ARV/ HIV to the CD4(T4) molecule: confirmation dependence, epitope mapping, antibody inhibition and potential for idiotypic mimicry. J. Immunol. 137:29372944.

21. Ardman, B., M. Kowalski, J. Bristol, W. Haseltine, and J. Sodroski. 1990 Effects on CD4 binding of anti-peptide sera to the fourth and fifth conserved domains of HIV-1 gp120. J. Acquired Immune Defic. Syndr. 3:206-214.

22. Schnittman, S. M., H. C. Lane, J. Roth, A. Burrows, T. M. Folks, J. H. Kehrl, S. Koenig, P. Berman, and A. S. Fauci. 1988. Characterization of GP120 binding to CD4 and an assay that measures the ability of sera to inhibit this binding. J. Immunol. 141:4181-4186.

23. Olshevsky, U., E. Helseth, C. Furman, J. Li, W. Haseltine, and J. Sodroski. 1990. Identification of individual human immunodeficiency virus type 1 gp120 amino acids important for CD4 receptor binding. J. Virol. 64:5701-5707.

24. Thali, M., U. Olshevsky, C. Furman, D. Gabuzda, M. Posner, and J. Sodroski. 1991. Characterization of a discontinuous human immunodeficiency virus type $1 \mathrm{gp} 120$ epitope recognized by a broadly reactive neutralizing human monoclonal antibody. J. Virol. 65:6188-6193.

25. Posner, M. R., T. Hideshima, T. Cannon, M. Mukherjee, K. H. Mayer, and R. A. Byrn. 1991. An IgG human monoclonal antibody which reacts with HIV-1/gp120, inhibits virus binding to cells, and neutralizes infection. J. Immunol. $146: 4325-4332$

26. Ho, D. D., J. A. McKeating, X. L. Li, T. Moudgil, E. S. Daar, N.-C. Sun, and J. E. Robinson. 1991. Conformational epitope on gp-120 important in CD4 binding and human immunodeficiency virus type 1 neutralization identified by a human monoclonal antibody. J. Virol. 65:489-493.

27. Tilley, S. A., W. J. Honnen, M. Racho, M. Hilgartner, and A. Pinter. 1991. A human monoclonal antibody against the CD4 binding site of HIV-1 gp120 exhibits potent, broadly neutralizing activity. Res. Virol. 142:247-259.

28. Hughes-Jones, N. C., J. M. Bye, D. Beale, and J. Coadwell. 1990. Nucleotide sequences and three-dimensional modelling of the $V_{H}$ and $V_{L}$ domains of two human monoclonal antibodies specific for the $\mathrm{D}$ antigen of the human Rh-bloodgroup system. Biochem. J. 268:135-140.

29. Andris, J., S. Johnson, S. Zolla-Pazner, and J. D. Capra. 1991. Molecular characterization of five human anti-human immunodeficiency virus type 1 antibody heavy chains reveals extensive somatic mutation typical of an antigen driven immune response. Proc. Natl. Acad. Sci. USA. 88:7783-7787.

30. Felgenhauer, M., J. Kohl, and F. Ruker. 1990. Nucleotide sequences of the cDNAs encoding the $\mathrm{V}$-regions of $\mathrm{H}$ - and $\mathrm{L}$-chains of a human monoclonal antibody specific to HIV-1-gp41. Nucleic Acids Res. 18:4927.

31. Gubler, U., and B. J. Hoffman. 1983. A simple and very efficient method for generating cDNA libraries. Gene (Amst.). 25:263-269.

32. Sanger, F., S. Nicklen, and A. R. Coulson. 1977. DNA sequencing with chain terminating inhibitors. Proc. Natl. Acad. Sci. USA. 74:5463.

33. Kabat, E. A., T. T. Wu, M. Reid-Miller, H. Perry, and K. S. Gottesman Sequences of Proteins of Immunological Interest. 4th ed. U. S. Department of Health Human Services, Washington, DC.

34. Mullinax, R. L., E. A. Gross, J. R. Amberg, B. N. Hay, H. H. Hogrefe M. M. Kubitz, A. Greener, M. Alting-Mees, D. Ardourel, J. M. Short, et al. 1990
Identification of human antibody fragment clones specific for tetanus toxoid in a bacteriophage lambda immunoexpression library. Proc. Natl. Acad. Sci. USA. 87:8095-8099.

35. Lee, K., H. F. Matsuda, T. Kinashi, M. Kodaira, and T. Honjo. 1987. A novel family of variable region genes of the human immunoglobulin heavy chain. J. Mol. Biol. 195:761-768.

36. Radoux, V., P. P. Chen, J. A. Sorge, and D. A. Carson. 1986. A conserved human germline $\mathrm{V}_{\mathrm{k}}$ gene directly encodes rheumatoid factor light chains. $J$. Exp. Med. 164:2119-2124.

37. Silverman, G. J., and D. A. Carson. 1990. Structural characterization of human monoclonal cold agglutinins: evidence for a distinct primary sequencedefined $\mathrm{V}_{\mathrm{H}} 4$ idiotype. Eur. J. Immunol. 20:351-356.

38. Sanz, I., P. Kelly, C. Williams, S. Schnoll, P. Tucker, and J. D. Capra. 1989. The smaller human $V_{H}$ gene families display remarkably little polymorphism. EMBO (Eur. Mol. Biol. Organ.) J. 8:3741-3748.

39. Chothia, C., and A. Lesk. 1987. Canonical structures for the hypervariable regions of immunoglobulins. J. Mol. Biol. 196:901-907.

40. Sanz, I., P. Casali, J. W. Thomas, A. L. Notkins, and J. D. Capra. 1989. Nucleotide sequences of eight human natural autoantibody $V_{H}$ regions reveals apparent restricted use of $V_{H}$ families. J. Immunol. 142:4054-4061.

41. Schilling, J., B. Clevinger, J. M. Davie, and L. Hood. 1980. Amino acid sequence of homogeneous antibodies to dextran and DNA rearrangements in heavy chain V-region gene segments. Nature (Lond.). 283:35-40.

42. Ichihara, Y., H. Matsuoka, and Y. Kurosawa. 1988. Organization of human immunoglobulin heavy chain diversity gene loci. EMBO (Eur. Mol. Biol. Organ.) J. 7:4141-4150.

43. Meek, K. D., C. D. Hasemann, and J. D. Capra. 1989. Novel rearrangements at the immunoglobulin D locus. J. Exp. Med. 170:39-57.

44. Eilat, D., and R. Fischel. 1991. Recurrent utilization of genetic elements in $\mathrm{V}$ regions of antinucleic acid antibodies from autoimmune mice. J. Immunol. 147:361-368.

45. Yamada, M., R. Wasserman, B. A. Reichard, S. Shane, A. J. Caton, and G. Rovera. 1991. Preferential utilization of specific immunoglobulin heavy chain diversity and joining segments in adult human peripheral blood B lymphocytes. J. Exp. Med. 173:395-407.

46. Sanz, I. 1991. Multiple mechanisms participate in the generation of diversity of human H chain CDR3 regions. J. Immunol. 147:1720-1729.

47. Alt, F., and D. Baltimore. 1982. Joining of immunoglobulin heavy chain gene segments: implications from a chromosome with evidence of three $\mathbf{D}-\mathrm{J}_{\mathbf{H}}$ fusions. Proc. Natl. Acad. Sci. USA. 79:4118-4122.

48. Kipps, T. J., and S. F. Duffy. 1991. Relationship of the CD5 B cell to human tonsillar lymphocytes that express autoantibody-associated cross-reactive idiotypes. J. Clin. Invest. 87:2087-2096.

49. Dersimonian, H., K. P. W. J. McAdam, C. Mackworth-Young, and B. D. Stollar. 1989. The recurrent expression of variable region segments in human IgM anti-DNA autoantibodies. J. Immunol. 142:4027-4033.

50. Silverman, G. J., R. E. Schohenloher, M. A. Accavitti, W. J. Koopman and D. A. Carson. 1990. Structural characterization of the second major crossreactive idiotype group of human rheumatoid factors. Arthritis Rheum. 33:13471360.

51. Goñi, F., P. P. Chen, B. Pons-Estel, D. A. Carson, and B. Frangione. 1985 Sequence similarities and cross-idiotypic specificity of $\mathrm{L}$ chains among human monoclonal IgM $_{\mathbf{k}}$ with anti-gammaglobulin activity. J. Immunol. 135:40734079.

52. Silverman, G. J., R. D. Goldfien, P. Chen, R. A. Mageed, R. Jefferis, F. Goni, B. Frangione, S. Fong, and D. Carson. 1988. Idiotypic and subgroup analysis of human monoclonal rheumatoid factors. J. Clin. Invest. 82:469-475.

53. Pascual, V., K. Victor, D. Lelsz, M. B. Spellerberg, T. J. Hamblin, K. M Thompson, I. Randen, J. Natvig, J. D. Capra, and F. K. Stevenson. 1991. Nucleotide sequence analysis of the $\mathrm{V}$ regions of two IgM cold agglutinins. J. Immunol. 146:4385-4391.

54. Kieber-Emmons, T., and H. Kohler. 1986. Towards a unifed theory of immunoglobulin structure-function relations. Immunol. Rev. 90:29-48.

55. Kipps, T. J., E. Tomhave, P. P. Chen, and D. A. Carson. 1988. Autoantibody-associated kappa light chain variable region gene expressed in chronic lymphocytic leukemia with little or no somatic mutation. Implications for etiology and immunotherapy. J. Exp. Med. 167:840-852.

56. Pratt, L. F., L. Rassenti, J. Larrick, B. Robbins, P. M. Banks, and T. J. Kipps. 1989. Ig V region gene expression in small lymphocytic lymphoma with little or no somatic hypermutation. J. Immunol. 143:699-705.

57. Kipps, T. J., E. Tomhave, P. P. Chen, and R. I. Fox. 1989. Molecular characterization of a major autoantibody associated cross-reactive idiotype in Sjögren's syndrome. J. Immunol. 142:4261-4268.

58. Lane, H. C., H. Masur, L. C. Edgar, G. Whalen, A. H. Rook, and A. S. Fauci. 1983. Abnormalities of B-cell activation and immunoregulation in patients with the acquired immunodeficiency syndrome. N. Engl. J. Med. 309:453458

59. Pascual, V., J. Andris, and J. D. Capra. 1990. Heavy chain variable region gene utilization in human antibodies. Int. Rev. Immunol. 5:231-238.

60. Hoch, S., and J. Schwaber. 1987. Identification and sequence of the Vh 
gene elements encoding a human anti-DNA antibody. J. Immunol. 139:16891693.

61. Sanz, I., H. Dang, M. Takei, N. Talal, and J. D. Capra. 1989. $V_{H}$ sequence of a human anti-Sm autoantibody. J. Immunol. 142:883-887.

62. Pratt, L., R. Szubin, D. A. Carson, and T. J. Kipps. 1991. Molecula characterization of a supratypic cross-reactive idiotype associated with IgM autoantibodies. J. Immunol. 147:2041-2046.

63. Silberstein, L. E., L. C. Jefferies, D. Friedman, J. S. Moore, P. C. Nowell, D. Roelcke, W. Pruzanski, J. Roudier, and G. J. Silverman. 1991. Variable region gene analysis of pathologic human autoantibodies to the related $\mathrm{i}$ and I red blood cell antigens. Blood. 78:2372-2386.

64. Leoni, J., J. Ghiso, F. Goni, and B. Frangione. 1991. The primary structure of the Fab fragment of protein KAU, a monoclonal immunoglobulin $\mathrm{M}$ cold agglutinin. J. Biol. Chem. 266:2836-2842.

65. Stevenson, F. K., M. Wrightham, M. J. Glennie, D. B. Jones, A. R. Cattan T. Feizi, T. J. Hamblin, and G. T. Stevenson. 1986. Antibodies to shared idiotypes as agents for analysis and therapy for human B cell tumors. Blood. 68:430436.

66. Davidson, A., A. Smith, H. Katz, J.-L. Preude-Homme, A. Solomon, and B. Diamond. 1989. A cross-reactive idiotype in anti-DNA antibodies defines an H-chain determinant present almost exclusively in IgG antibodies. J. Immunol. 143:174-180.

67. Adderson, E. E., P. G. Shakelford, A. Quinn, and W. L. Carroll. 1991. Restricted Ig $\mathrm{H}$ chain $\mathrm{V}$ gene usage in the human antibody response to Haemophilus influenzae type b capsular polysaccharide. J. Immunol. 147:1667-1674.

68. Schreiber, J. R., M. Patawaran, M. Tosi, J. Lennon, and G. B. Pier. 1990. Anti-idiotype induced, lipopolysaccharide-specific antibody response to Pseudomonas aeruginosa. J. Immunol. 144:1023-1029.

69. Morrow, W. J. W., I. Gaston, T. Anderson, N. Haigwood, M. S. McGrath, J. Rosen, and K. S. Steimer. 1990. Anti-idiotypic antisera raised against monoclonal antibody specific for a p24 gag region epitope detects a common interspecies idiotype associated with anti-HIV responses. Viral Immunol. 3:99-109.
70. Müller, S., H.-T. Wang, S.-V. Kaveri, S. Chattopadhyay, and H. Köhler. 1991. Generation and specificity of monoclonal anti-idiotypic antibodies against human HIV-specific antibodies. I. Cross-reacting idiotopes are expressed in subpopulations of HIV-infected individuals. J. Immunol. 147:933-941.

71. Chen, P. P., K. Albrandt, T. J. Kipps, V. Radoux, F.-T. Liu, and D. A. Carson. 1987. Isolation and characterization of human VkIII germ-line genes. Implications for the molecular basis of human VkIII light chain diversity. $J$. Immunol. 139:1727-1733.

72. Pons-Estel, B., F. Goni, A. Solomom, and B. Frangione. 1984. Sequence similarities among kIIIb chains of monoclonal human IgMk autoantibodies. $J$. Exp. Med. 160:893-904.

73. Carson, D. A., and S. Fong. 1983. A common idiotype on human rheumatoid factors identified by a hybridoma antibody. Mol. Immunol. 20:1081-1087.

74. Crowley, J. J., R. D. Goldfien, R. E. Schrohenloher, H. L. Spiegelberg, G. J. Silverman, R. A. Mageed, R. Jefferis, W. J. Koopman, D. A. Carson, and S. Fong. 1988. Incidence of three cross-reactive idiotypes on human rheumatoid factor paraproteins. J. Immunol. 140:3411-3418.

75. Silverman, G. J., D. A. Carson, K. Patrick, J. H. Vaughan, and S. Fong. 1987. Expression of a germline human kappa chain-associated cross-reactive idiotype after in vitro and in vivo infection with Epstein-Barr virus. Clin. Immunol. Immunopathol. 43:403-411.

76. Newkirk, M. M., H. Gram, G. F. Heinrich, L. Ostberg, J. D. Capra, and R. L. Wasserman. 1988. Complete protein sequences of the variable regions of the cloned heavy and light chains of a human anti-cytomegalovirus antibody reveal a striking similarity to human monoclonal rheumatoid factors of the Wa idiotypic family. J. Clin. Invest. 81:1511-1518.

77 . Schroeder, H. W. J. L. Hillson, and R. M. Perlmutter. 1987. Early restriction of the human antibody repertoire. Science (Wash. DC). 238:791-793.

78. Kipps, T. J., B. A. Robbins, and D. A. Carson. 1990. Uniform high frequency expression of autoantibody-associated cross-reactive idiotypes in the primary B cell follicles of human fetal spleen. J. Exp. Med. 171:189-196. 